Article

\title{
Thermal-Energy Performance of Bulk Insulation Coupled with High-Albedo Roof Tiles in Urban Pitched Residential Roof Assemblies in the Hot, Humid Climate
}

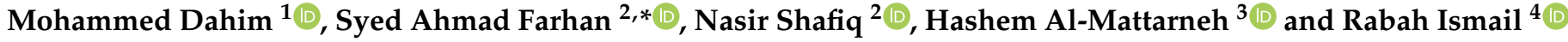 \\ 1 Vice Presidency for Project Management, King Khalid University, Abha 61421, Saudi Arabia; \\ madahim@kku.edu.sa \\ 2 Institute of Self-Sustainable Building for Smart Living, Universiti Teknologi PETRONAS, \\ Seri Iskandar 32610, Malaysia; nasirshafiq@utp.edu.my \\ 3 Department of Civil Engineering, Yarmouk University, Irbid 21163, Jordan; hashem.mattarneh@yu.edu.jo \\ 4 Department of Civil Engineering, Jadara University, Irbid 21110, Jordan; r.ismail@jadara.edu.jo \\ * Correspondence: syed.af_g02626@utp.edu.my
}

check for

updates

Citation: Dahim, M.; Farhan, S.A.; Shafiq, N.; Al-Mattarneh, H.; Ismail, R. Thermal-Energy Performance of Bulk Insulation Coupled with High-Albedo Roof Tiles in Urban Pitched Residential Roof Assemblies in the Hot, Humid Climate. Sustainability 2022, 14, 2867. https:// doi.org/10.3390/su14052867

Academic Editor: Wei-Hsin Chen

Received: 14 January 2022

Accepted: 26 February 2022

Published: 1 March 2022

Publisher's Note: MDPI stays neutral with regard to jurisdictional claims in published maps and institutional affiliations.

Copyright: (c) 2022 by the authors. Licensee MDPI, Basel, Switzerland. This article is an open access article distributed under the terms and conditions of the Creative Commons Attribution (CC BY) license (https:// creativecommons.org/licenses/by/ $4.0 /)$.

\begin{abstract}
The high rate of heat transfer through the residential roof assembly aggravates the condition of indoor thermal discomfort. Bulk insulation can be installed in the assembly to improve thermal performance. However, although it can efficiently reduce diurnal heat transfer from the outdoor environment into the indoor space through the roof assembly, it can also suppress nocturnal heat transfer in the opposite direction. Alternatively, high-albedo roof tiles employ cool colors to reflect heat at the roof surface, whereas bulk insulation hinders the conduction of heat through the roof assembly. In light of the potential of high-albedo roof tiles and bulk insulation in reducing heat transfer, thermal-energy performance of an urban pitched residential roof assembly, which adopted varying configurations of high-albedo roof tiles and bulk insulation under a hot, humid climate, was evaluated. Energy savings were generated, which were $15.13 \%$ when the change from a conventional to a high-albedo roof surface was performed, and $17.00 \%$ when the installation of bulk insulation was performed on the high-albedo roof assembly.
\end{abstract}

Keywords: air conditioner; cooling load; heat conduction; residential building; roof insulation; roof tile color; solar reflectance

\section{Introduction}

Buildings in countries that have hot, humid climates are exposed to intense solar radiation during the day, owing to the high altitude of the sun path [1,2]. In particular, the roof receives the highest amount of solar radiation in comparison to other components of the building envelope by virtue of the horizontal orientation and higher elevation of the roof $[3,4]$.

Malaysia, which is located in Southeast Asia from $1^{\circ}$ to $7^{\circ}$ north of the equator [1], has a hot, humid climate throughout the year [1,5]. Its climate can be classified as a tropical rainforest climate, as per the Köppen-Geiger climate classification [6]. According to the annual moving averages reported in Tang [5] for selected urban areas, namely Kota Kinabalu, Kuantan, Kuching, Malacca and Subang Jaya, mean daily temperatures of Malaysia, from 1956 to 2016 , ranged between $25.0^{\circ} \mathrm{C}$ and $28.7^{\circ} \mathrm{C}$. Recently, the Malaysian Meteorological Department revealed that $38.6^{\circ} \mathrm{C}$ was the highest peak daily temperature in Malaysia in 2020, which was recorded in Alor Setar [7]. Previously in 1998, a higher peak daily temperature of $40.1^{\circ} \mathrm{C}$ was recorded in Chuping [7]. The average duration of exposure to sunshine throughout Malaysia ranged from six to eight hours per day [8,9].

Typical urban residential buildings in Malaysia are predominantly low-rise with pitched roof assemblies, where the heat transfer through the roof accounts for between $50 \%$ and $70 \%$ of the total heat gain in the indoor space beneath the roof [10]. The high 
rate of heat transfer through the residential roof assembly aggravates the condition of indoor thermal discomfort experienced by the occupants. Accordingly, dependence toward air conditioners increases, which is a huge concern, as air conditioners heavily consume energy [8,9].

Bulk insulation restricts the transfer of heat via conduction and convection by trapping air in millions of pockets within bulky materials that possess low density. Common bulk insulation materials employed for various applications, include, among others, cellulose, glass wool, mineral wool, polyester, polyisocyanurate, polystyrene and polyurethane. Bulk insulation products can be manufactured in various forms, which are, but not limited to, batts, loose-fills, rigid boards and rolls. Bulk insulation can be installed in the residential roof assembly to improve thermal performance owing to the presence of miniature air spaces that hinder heat conduction [11], which can potentially reduce the intensity and duration of the operation of air conditioners by the occupants [12]. Innovations pertaining to bulk insulation materials have been proposed by, among others, Husna et al. [13] and Ismail et al. [14], who adopted nano-materials that possess ultra-low thermal conductivity, as well as Nuruddin et al. [15], Farhan et al. [16] and Omar et al. [17], who adopted natural fibers, which are greener than synthetic fibers. Although bulk insulation has great potential in improving the thermal-energy performance of the roof assembly, its rate of adoption in Malaysia is still low [18]. Increases in cost related to the purchase, installation and maintenance of the insulation material, as well as lack of awareness and understanding of the long-term benefits of employing insulation, influence the decisions opted by homeowners [18]. Consequently, the omission of bulk insulation from the roof assembly may result in an increase in the rate of heat transfer through the roof assembly and into the indoor space. Hence, thermal-energy performance of the building during hours of high exposure to intense solar radiation will be negatively impacted.

Residential roof assemblies in Malaysia are typically lightweight and pitched. They comprise roof tiles, attic spaces and ceiling boards. For lightweight roofs, Malaysian Standard: Energy Efficiency and Use of Renewable Energy for Residential Buildings (MS 2680:2017) [19] recommends the installation of insulation within the roof assembly. Furthermore, a minimum thermal resistance ( $R$-value) of $2.50 \mathrm{~m}^{2} \mathrm{~K} / \mathrm{W}$ has been set as a mandatory compliance criterion for lightweight roofs as stated in MS 2680:2017 [19], Green Building Index Assessment Criteria for Residential New Construction [20], and Selangor Uniform Building By-Laws [21].

Previous studies on building insulation paid more attention to wall insulation in cold climates [22], and less emphasis was given to roof insulation in hot climates. In Malaysia, previous research pertaining to thermal performance evaluation of insulation materials installed in residential roof assemblies is limited to the studies of Farhan et al. [16], Halim et al. [23], Irwan et al. [24,25], Ismail et al. [14], Morris et al. [26], Nuruddin et al. [15,27], Puad et al. [28] and Zakaria et al. [29]. Findings indicated that installing roof insulation efficiently reduced diurnal heat transfer from the outdoor environment into the indoor space through the roof assembly. Conversely, findings also revealed that the presence of insulation suppressed nocturnal heat transfer through the roof assembly, which is in the opposite direction to that of the diurnal heat transfer. Consequently, the nocturnal energy consumption owing to the use of air conditioners will increase in view of the fact that indoor thermal comfort has to be sustained throughout the night in order to facilitate adequate rest and sleep among the occupants.

Alternatively, Al-Obaidi et al. [4], Al Yacouby et al. [30] and Farhan et al. [31] studied the effect of high-albedo roofs without insulation under the climate of Malaysia. Highalbedo roof tiles reflect heat at the roof surface, whereas bulk insulation hinders the conduction of heat through the roof assembly. Adoption of high-albedo roofs has been reported in Synnefa et al. [32] to be effective at increasing thermal-energy performance for widely differing climate classes. Prevalently, previous studies have attempted to increase the albedo of roof tiles by applying high-albedo coatings. The coatings can be classified according to their binders, such as cementitious or elastomeric coatings. Alternatively, the coatings can 
also be categorized according to their carriers, such as solvent- or water-based coatings [33]. Essentially, for application on high-albedo roofs, the coatings are required to possess superficial thermal-optical properties that are appropriate for maintaining, under exposure to solar radiation, surface temperatures that are appreciably lower than those of conventional roofs. In general, high-albedo coatings that possess pre-eminent thermal-optical properties are those that are white in color. However, as aesthetics of buildings cannot be disregarded, studies have been conducted to develop innovative coatings, such as those that possess solar-reflective surfaces with non-white colors, those that are thermochromic, or those that are doped with phase-change materials [33].

Despite the potential for improving the thermal-energy performance, adoption of highalbedo roofs in countries that are exposed to the tropical rainforest climate is still low $[9,30]$. In particular, within the region of Southeast Asia, research on the effect of high-albedo roofs is currently deficient. Exclusive of the studies that were conducted in Malaysia, which are Al-Obaidi et al. [4], Al Yacouby et al. [30] and Farhan et al. [31], the research is limited to the studies of Syuhada and Maulana [34] in Indonesia, Zingre et al. [35] in Singapore and Thongkanluang et al. [36] in Thailand.

Although Al-Obaidi et al. [4] and Al Yacouby et al. [30] studied the effect of highalbedo roofs by varying the color of the roof surface, their methodologies employed test cells that did not comply with the clauses in Uniform Building By-Laws 1984 (UBBL 1984) [37] for habitable rooms of residential buildings in Malaysia. The methodology adopted in Farhan et al. [31] later addressed the shortcomings of the test cells employed in Al-Obaidi et al. [4] and Al Yacouby et al. [30] but focused solely on the effect of highalbedo roofs without considering its coupling with insulation. The scope of Syuhada and Maulana [34] zoomed in on zinc roofs and excluded the adoption of roof tiles. Zingre et al. [35] adopted a methodology that concentrated on flat roofs and did not consider pitched roof assemblies that have attic spaces and ceiling boards. Thongkanluang et al. [36] focused on synthesizing a coating material for potential application on the surface of high-albedo roofs, without performing any study on heat transfer through the roof assembly that endures exposure to solar radiation.

Hence, new studies are required to address the shortcomings of previous research on the effect of high-albedo roofs, in particular, those that zoom in on pitched roof assemblies that have roof tiles, attic spaces and ceiling boards, together with the adoption of insulation, under a hot, humid climate. In light of the potential of high-albedo roof tiles and bulk insulation in reducing heat transfer, thermal-energy performance of an urban pitched residential roof assembly, which adopted varying configurations of high-albedo roof tiles and bulk insulation under a hot, humid climate, was evaluated.

\section{Materials and Methods}

The thermal-energy performance of an urban pitched residential roof assembly was evaluated by developing a building information model using Integrated Environmental Solutions < Virtual Environment $>$ (IESVE), which is a building information modeling (BIM) tool. Thermal-energy and computational fluid dynamics (CFD) analyses were performed on the model. Varying configurations of high-albedo roof tiles and bulk insulation within the roof assembly were adopted. The roof was exposed to the hot, humid climate of Shah Alam in Malaysia, which is an urban area.

The second law of thermodynamics states that the total entropy, which is a measure of the disorder of a system and its environment, will never decrease. Therefore, heat transfer through the residential roof assembly will occur from the hotter to the colder bodies, as the building and its environment attempt to gain entropy over time and reach its maximum, which is when thermal equilibrium is achieved [38]. Accordingly, as outdoor and sky conditions change over time throughout the day, magnitude and direction of heat transfer through the roof assembly will continually change in conformity with the second law of thermodynamics. 
In the present study, evaluation of thermal-energy performance considered the conduction, convection and radiation modes of heat transfer through the roof assembly. Thermal properties of materials that constitute the assembly were also taken into account. The rate of heat transfer by conduction $\left(Q_{\text {conduction }}\right)$, convection $\left(Q_{\text {convection }}\right)$ and radiation $\left(Q_{\text {radiation }}\right)$ can be expressed by Fourier's Law as per Equation (1) [39], Newton's Law of Cooling as per Equation (2) [40] and Stefan-Boltzmann's Law as per Equations (3) and (4) [41].

$$
Q_{\text {conduction }}=k A \frac{d T}{d x}
$$

where $k$ is the thermal conductivity of the material expressed in $\mathrm{W} / \mathrm{mK}, A$ is the crosssectional area perpendicular to heat flow expressed in $\mathrm{m}^{2}$, and $\frac{d T}{d x}$ is the temperature gradient expressed in $\mathrm{K} / \mathrm{m}$.

$$
Q_{\text {convection }}=h_{c} A\left(T_{s}-T_{f}\right)
$$

where $h_{c}$ is the surface heat transfer coefficient, $A$ is the surface area, $T_{S}$ is the surface temperature, and $T_{f}$ is the fluid temperature.

$$
\begin{gathered}
Q_{\text {radiation }}=\sigma A_{1} \varepsilon_{1}\left(T_{1}^{4}-T_{2}{ }^{4}\right) \\
Q_{\text {radiation }}=h_{r} A_{1}\left(T_{1}-T_{2}\right)
\end{gathered}
$$

where $\sigma$ is the Stefan-Boltzmann constant, $h_{r}$ is the coefficient of heat transfer, $A_{1}$ is the area of the first surface, $\varepsilon_{1}$ is the emissivity of the first surface, $T_{1}$ is the absolute temperature of the first surface, and $T_{2}$ is the absolute temperature of the second surface.

The ability of the roof surface to reject solar heat, as indicated by the solar reflectance index (SRI), was also taken into consideration. SRI refers to the relative steady-state temperature of a surface with respect to a standard white, which is given the SRI value of 100, and a standard black, which is given the SRI value of 0 , under standard solar and ambient conditions. It is calculated as per Equation (5) [42]. As its definition and method of calculation are based on the steady-state temperatures of a standard black, which has a reflectance of 0.05 and an emittance of 0.90 , and a standard white, which has a reflectance of 0.80 and an emittance of 0.90 , it is possible for SRI values to be slightly negative or exceed 100 .

$$
S R I=\frac{\left(T_{\text {black }}-T_{\text {surface }}\right)}{\left(T_{\text {black }}-T_{\text {white }}\right)} \times 100
$$

where $T_{\text {black }}, T_{\text {white }}$ and $T_{\text {surface }}$ are steady-state temperatures of the standard black, standard white and material surface, respectively, which are derived from measured values of solar reflectance and infrared emittance of the material surface according to the calculations in the Standard Practice for Calculating Solar Reflectance Index of Horizontal and Low-Sloped Opaque Surfaces (ASTM E1980-11) [43].

Adoption of high-albedo roof tiles and bulk insulation within the roof assembly were aimed toward developing an energy-efficient roof assembly. Monitoring of the energyefficiency considered the cooling load and energy savings, which signify the level of indoor thermal comfort. A conceptual framework of the present study is outlined in Figure 1. 


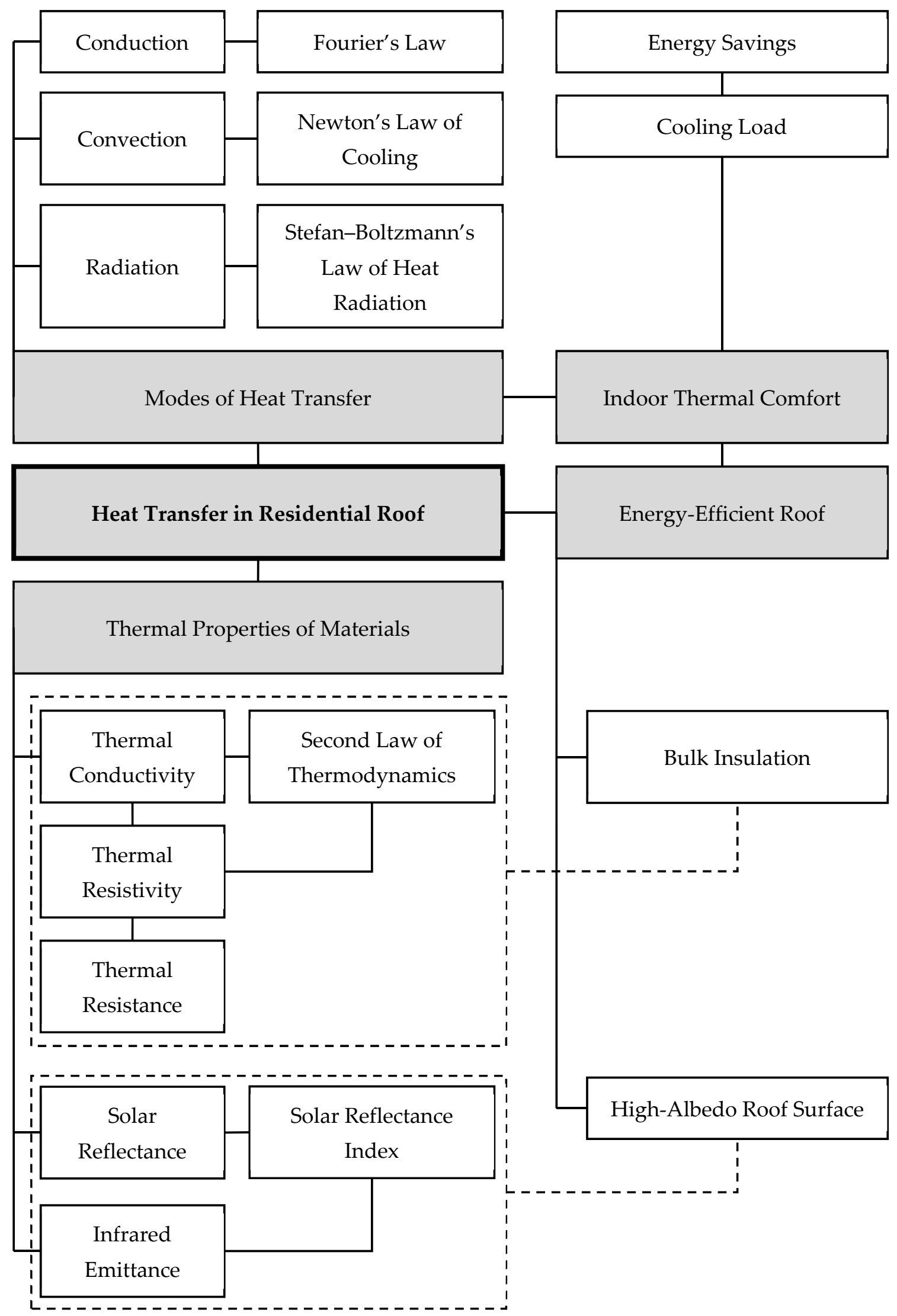

Figure 1. Conceptual framework of the present study. 
BIM was selected as the methodology, as it is capable of assisting the decision-making process when it comes to sustainable design of buildings. BIM has been employed in previous studies to perform sustainable design of residential buildings that are exposed to the hot, humid climate of Malaysia. Amir et al. [44], Gardezi et al. [45] and Jamaludin et al. [46] developed building information models of pre-determined types of residential buildings. Alternatively, building information models developed in Farhan et al. [31], Halim et al. [23], Irwan et al. [24,25] and Morris et al. [26] were those of test cells that represent the conditions of a habitable space in typical urban residential buildings in Malaysia. BIM simulation data that were collected from the building information models can be validated by conducting field measurements and comparing the measured data with their counterparts from the BIM simulation based on Equation (6) as in Vangimalla et al. [47].

$$
P D_{S D-F M}=\frac{S D-F M}{F M} \times 100 \%
$$

where $S D$ and FM are the simulation and field measurement data, respectively, and $P D_{S D-F M}$ is the percentage difference between the simulation and field measurement data.

Acceptable $P D_{S D-F M}$ values adopted in Vangimalla et al. [47] and Leng et al. [48] are $15 \%$ and $20 \%$, respectively, which were determined based on the $10 \%$ to $20 \%$ acceptable range recommended in Maamari et al. [49].

In the present study, two test cells, as shown in Figure 2, were constructed at the site location of $3.07^{\circ} \mathrm{N}, 101.50^{\circ} \mathrm{E}$ in Shah Alam, as shown in Figure 3. The test cells are identical, barring the roof tile color, where red and white roof tile colors were adopted, as shown in Figures 4 and 5, to represent conventional and high-albedo roofs, respectively. Thermocouples and data loggers were installed in the test cells to collect air and surface temperature data throughout the whole year of 2021.

Inspections were conducted prior to commencement of data collection, as well as once per week after the commencement, to ascertain the accuracy of data throughout the data collection. The inspections were conducted by comparing air and surface temperature data that were recorded using primary data loggers, which were mounted to the test cells, with those that were recorded using secondary data loggers of the same model that were minimally used. For the surface temperature data, their accuracy was further ascertained by performing supplementary comparisons between the temperatures that were measured using thermocouples, which were then recorded by the data loggers, with those that were manually measured using a thermal imaging camera.

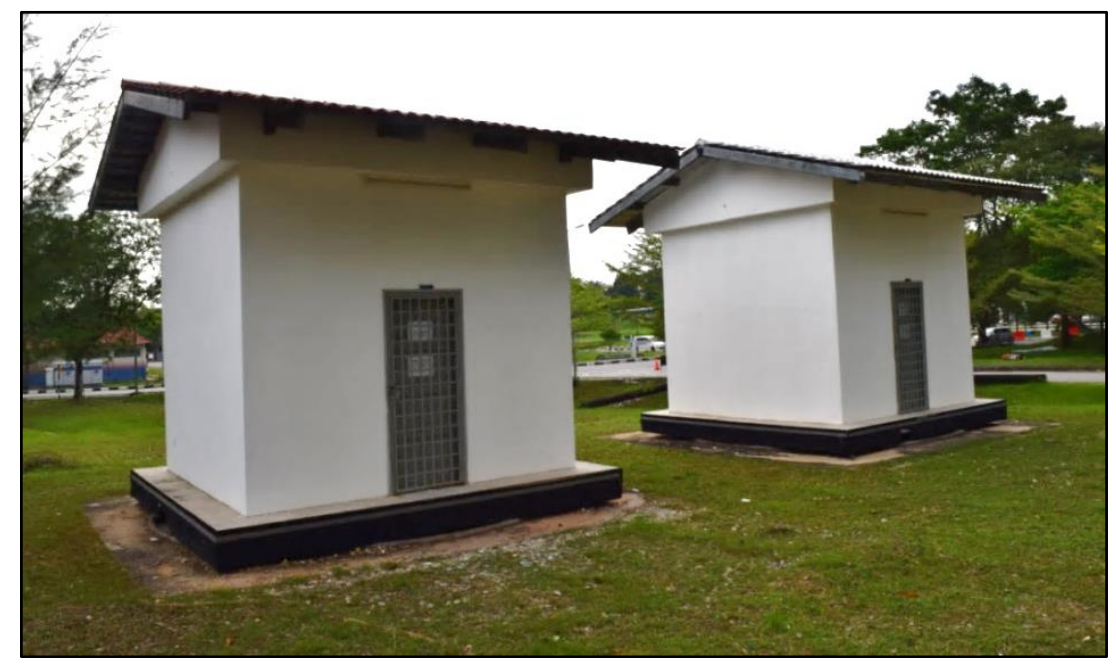

Figure 2. Two test cells. 


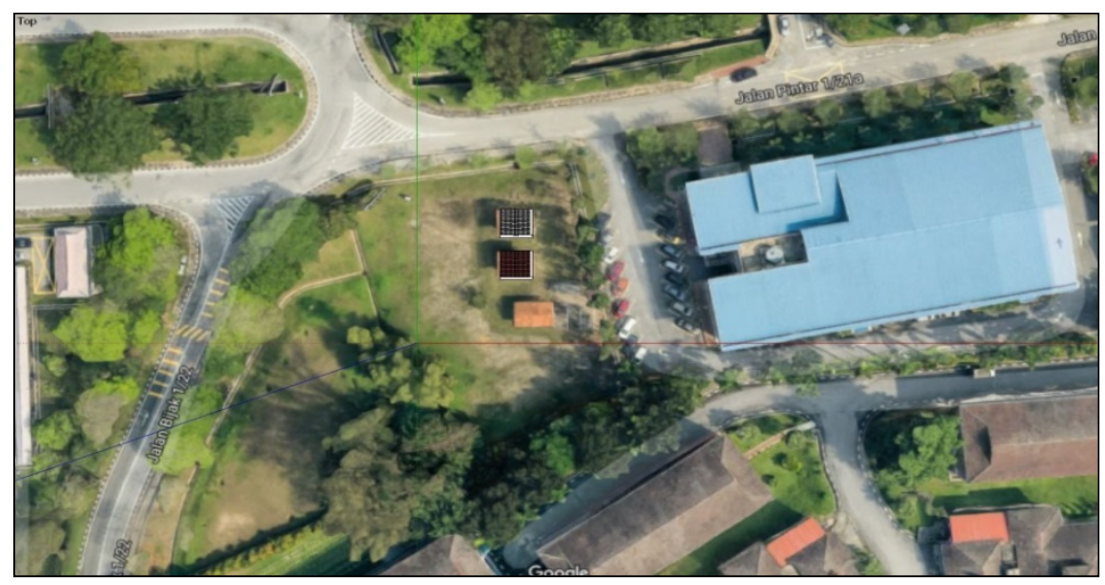

Figure 3. Plan view of the site location of the test cells.

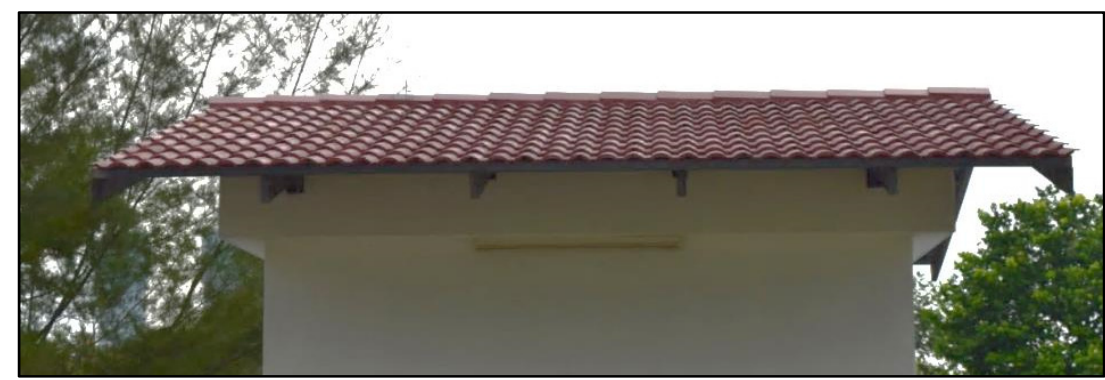

Figure 4. Red (conventional) roof of one of the test cells.

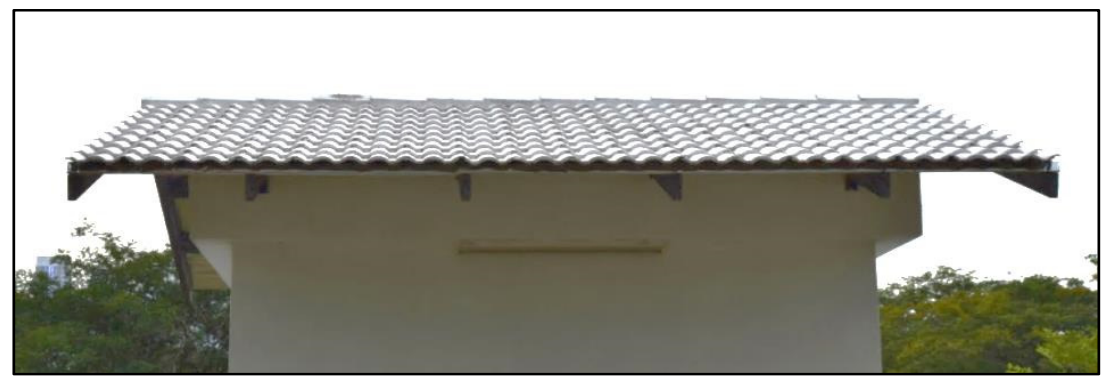

Figure 5. White (high-albedo) roof of one of the test cells.

The test cells were $4 \mathrm{~m}$ long, $4 \mathrm{~m}$ wide and $3 \mathrm{~m}$ high. The dimensions were selected as such to fulfil minimum size requirements as specified in UBBL 1984 [37], while minimizing the size of the test cells for feasibility of the experiment. The minimum base area, height and width of a habitable room in residential buildings were $11 \mathrm{~m}^{2}, 2.5 \mathrm{~m}$ and $2 \mathrm{~m}$, respectively.

Conventional materials were employed to construct the test cells, as itemized in Table 1 , inclusive of the density, thermal conductivity ( $k$-value), specific heat and thickness of each material, with the aim of creating the conditions of a habitable space in typical urban residential buildings in Malaysia. 
Table 1. Materials employed to construct the test cells.

\begin{tabular}{|c|c|c|c|c|c|}
\hline Component & Material & $\begin{array}{l}\text { Density } \\
\left(\mathrm{kg} / \mathrm{m}^{3}\right)\end{array}$ & $\begin{array}{l}\text { Specific Heat } \\
(\mathrm{J} / \mathrm{kgK})\end{array}$ & $\begin{array}{l}k \text {-Value } \\
\text { (W/mK) }\end{array}$ & $\begin{array}{c}\text { Thickness } \\
\text { (mm) }\end{array}$ \\
\hline Roof & Cement Tile & 1890 & 1000 & 0.836 & 10.0 \\
\hline Ceiling & Cement Board & 720 & 1000 & 0.250 & 4.5 \\
\hline Window & Clear Float Glass & 2800 & 800 & 0.810 & 6.0 \\
\hline Door & Solid Timber & 702 & 2720 & 0.138 & 38.0 \\
\hline \multirow{3}{*}{ Wall } & Cement Plaster & 1690 & 840 & 0.533 & 18.0 \\
\hline & Clay Brick & 1800 & 800 & 1.154 & 114.0 \\
\hline & Cement Plaster & 1690 & 840 & 0.533 & 18.0 \\
\hline Floor & Reinforced Concrete & 2400 & 1000 & 1.442 & 50.0 \\
\hline
\end{tabular}

The test cell was modeled in IESVE as a building information model. An axonometric projection of the model is shown in Figure 6. Two-dimensional plan, front and rear, and left and right views of the model are shown in Figure 7.

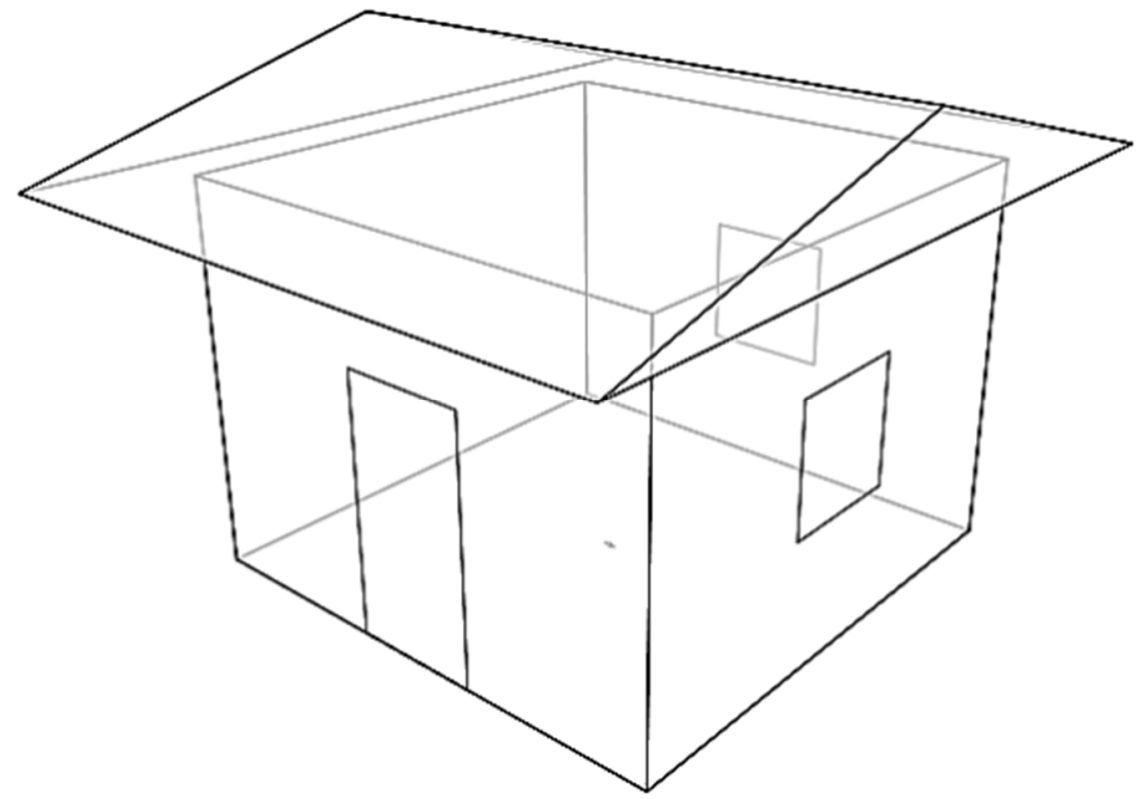

Figure 6. Axonometric projection of the building information model of the test cell.

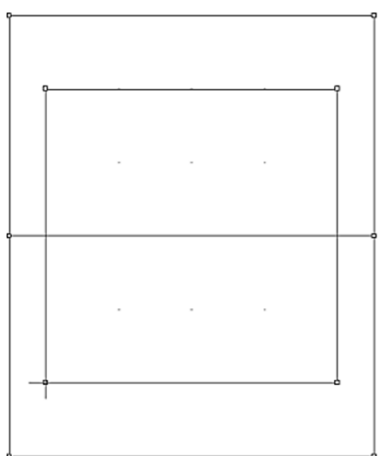

(a)

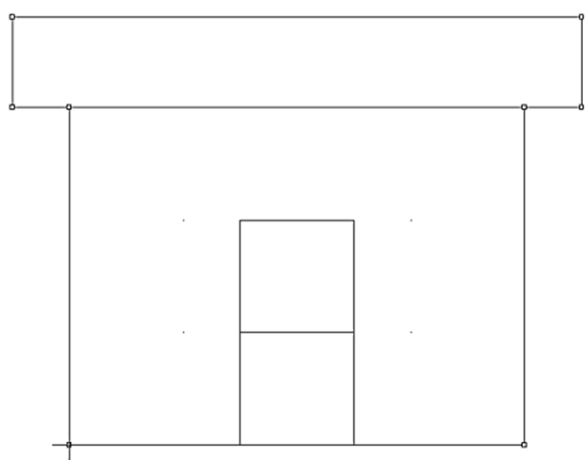

(b)

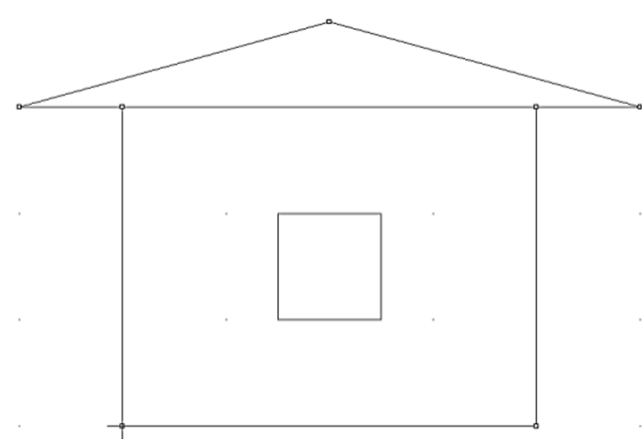

(c)

Figure 7. Two-dimensional views of the building information model of the test cell: (a) plan; (b) front and rear; (c) left and right. 
Thermal-energy performance of the roof assembly of the building information model was evaluated by performing thermal-energy and CFD analyses using Apache and MicroFlo, respectively, in IESVE. SRI values of the roof surfaces were calculated from solar reflectance and infrared emittance values of roof surfaces of roof tile samples, which were obtained from laboratory measurements. Thermal-energy analysis was performed for a whole typical meteorological year (TMY) for the site location of the test cells at $3.07^{\circ} \mathrm{N}$, $101.50^{\circ} \mathrm{E}$ in Shah Alam, Malaysia. Meteorological data, inclusive of solar irradiance, were generated by Meteonorm, based on data obtained from weather stations, geostationary satellites and globally calibrated aerosol climatology, as well as sophisticated interpolation models [50]. Roof-surface and attic-air temperature data generated from the thermal-energy analysis throughout the TMY were averaged to obtain annual-averaged 24-h profiles. The CFD analysis generated indoor temperature contours at peak diurnal outdoor temperature and the trough of nocturnal outdoor temperature. Configuration of the roof assembly was varied according to the roof tile color and presence of insulation to create three building information models as presented in Table 2. Then, 100-mm thick mineral wool was employed within the roof assembly as bulk insulation, as it is commonly used for building insulation in Malaysia.

Table 2. Roof assembly configurations of building information models.

\begin{tabular}{ccc}
\hline Building Information Model & Roof Tile Color & Bulk Insulation \\
\hline Conventional & Red & Nil \\
High-Albedo & White & Nil \\
High-Albedo + Bulk Insulation & White & Mineral Wool \\
\hline
\end{tabular}

The evaluation of thermal-energy performance considered the operation of a unit of a 950-W air conditioner for cooling of the indoor space with a set-point temperature of $24^{\circ} \mathrm{C}$ as recommended in Malaysian Standard: Energy Efficiency and Use of Renewable Energy for Non-Residential Buildings (MS 1525:2019) [51] and also adopted in Halim et al. [23] and Irwan et al. [24,25]. Daily, weekly and monthly indoor cooling profiles were configured based on the profiles adopted in Halim et al. [23], Irwan et al. [24,25], Tang and Chin [52] and Zakaria et al. [29], which also focused on residential buildings in Malaysia. Simulation settings were configured with the assumption that no occupants and furniture are present in the indoor space, and the door and windows are closed throughout the year.

The methodology of the study is elucidated in Figures 8 and 9. 


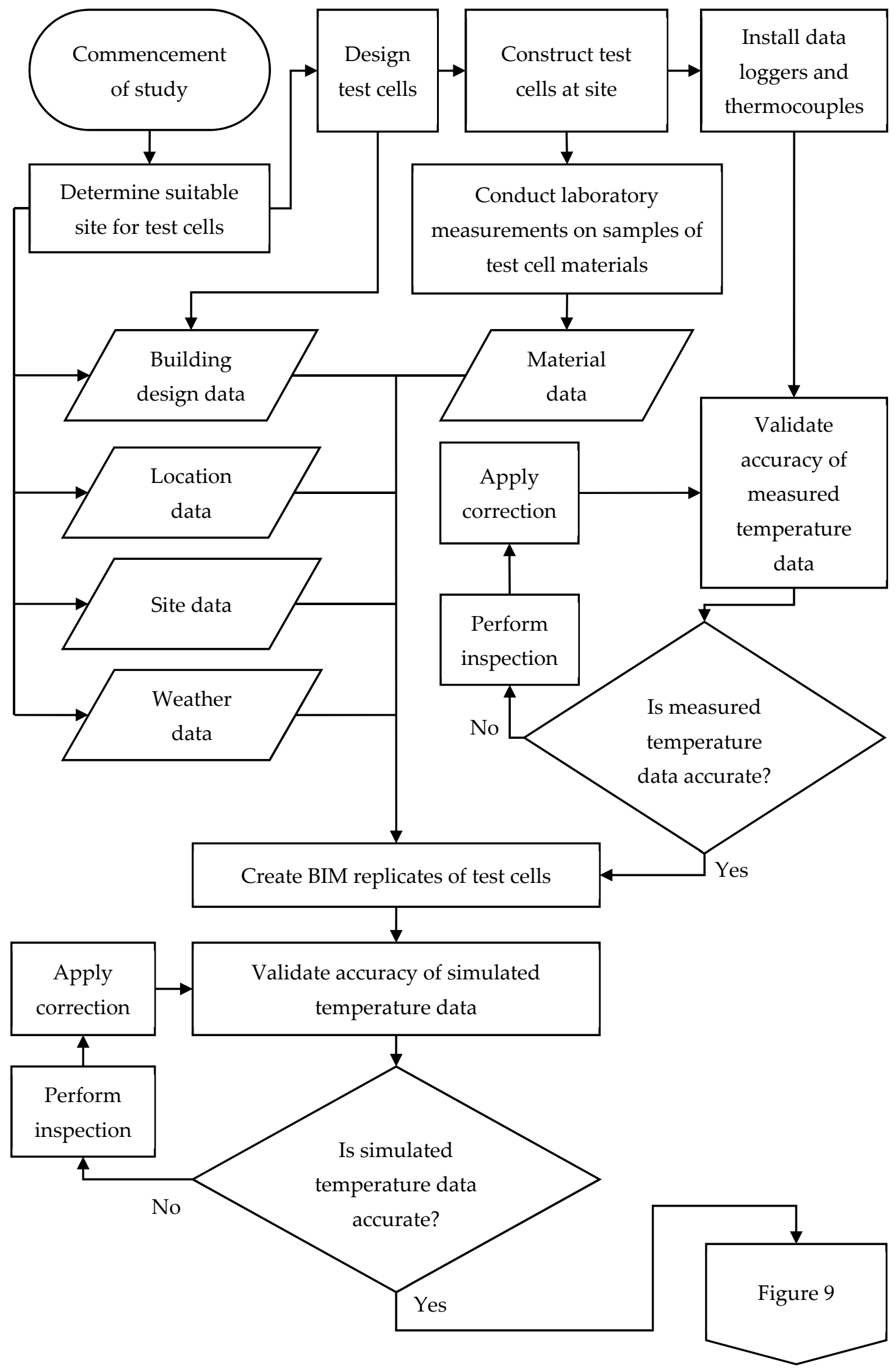

Figure 8. Methodology of the present study. 


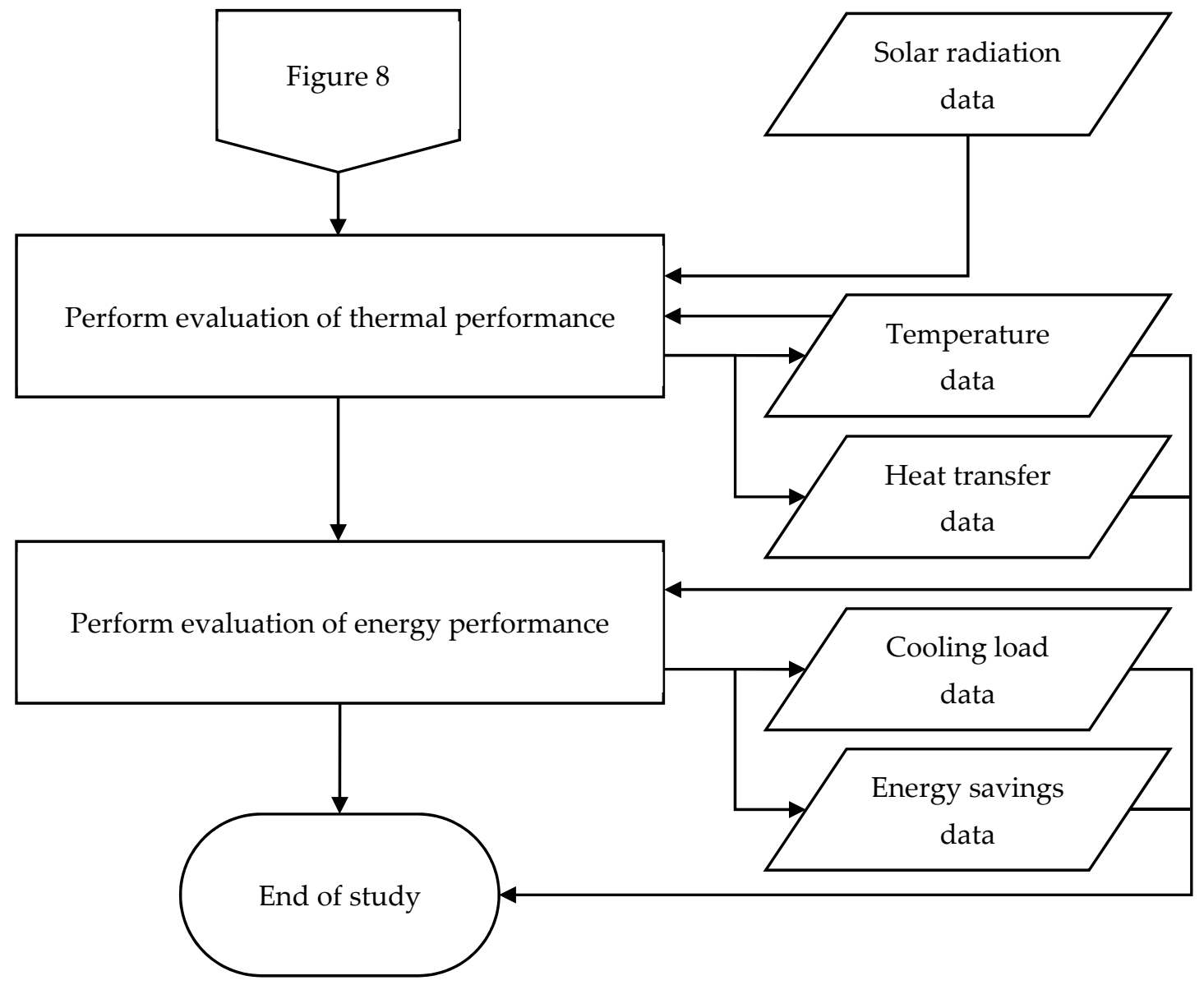

Figure 9. Methodology of the present study (continued).

\section{Results and Discussion}

The site location of the test cells at $3.07^{\circ} \mathrm{N}, 101.50^{\circ} \mathrm{E}$ in Shah Alam, Malaysia is within the tropical rainforest region as per the Köppen-Geiger climate classification [6]. Consequently, the test cells are exposed to a hot, humid climate throughout the year $[1,5]$. Minimum, mean and maximum annual-averaged profiles of solar irradiance and outdoor air temperature throughout the TMY of the location are presented in Figure 10. For the most part, solar irradiance throughout diurnal periods is relatively high, particularly in the afternoon, owing to the high altitude of the sun path as mentioned in Alam et al. [1] and Al-Obaidi et al. [2]. Minimum, mean and maximum solar irradiance profiles peaked at $73.36,587.52$ and $1070.25 \mathrm{~W} / \mathrm{m}^{2}$, respectively. The solar irradiance culminated at 13:30, which is about halfway through the diurnal period. Inversely, there is zero solar irradiance throughout the nocturnal period from 20:30 to 5:30. Accordingly, as outdoor air temperature is directly impacted by solar irradiance, the trend of the outdoor air temperature profiles trailed those of solar irradiance. Minimum, mean and maximum profiles of the outdoor air temperatures peaked at $26.9,31.23$ and $36.00{ }^{\circ} \mathrm{C}$, respectively, with the temperatures culminating from 15:30 to $16: 30$. 
(a)

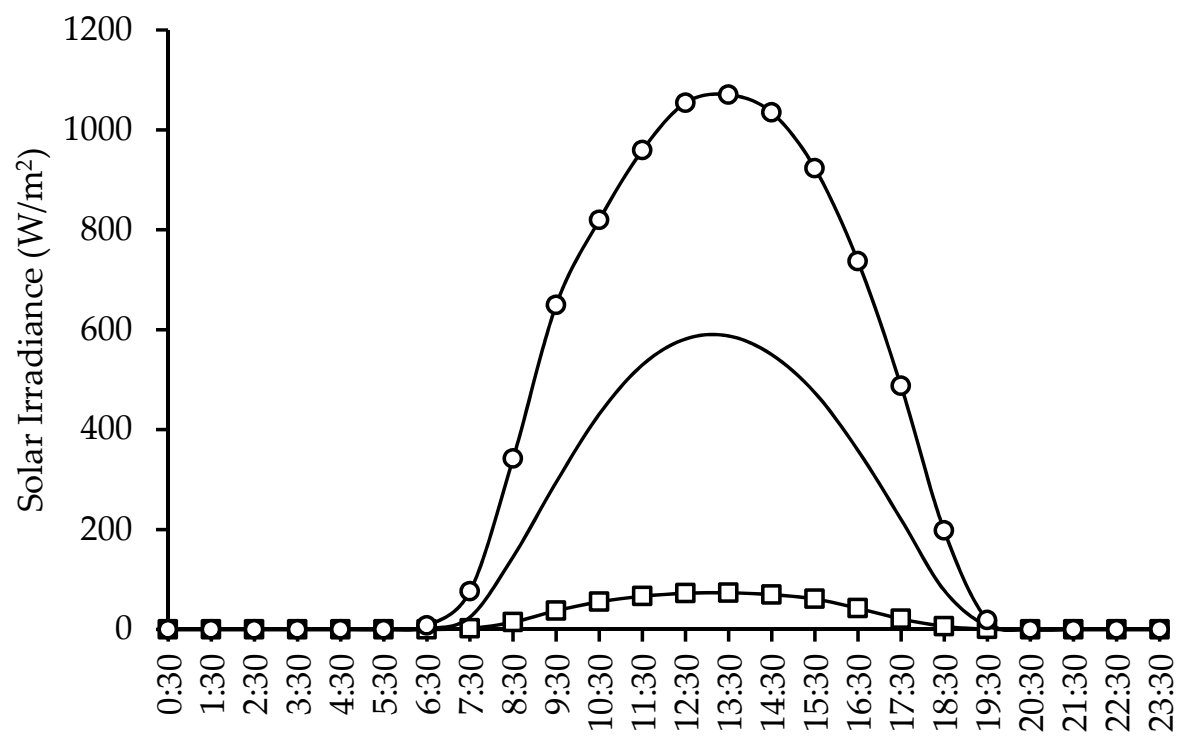

Time

$\multimap$-Minimum $\longrightarrow$ Mean - Maximum

(b)

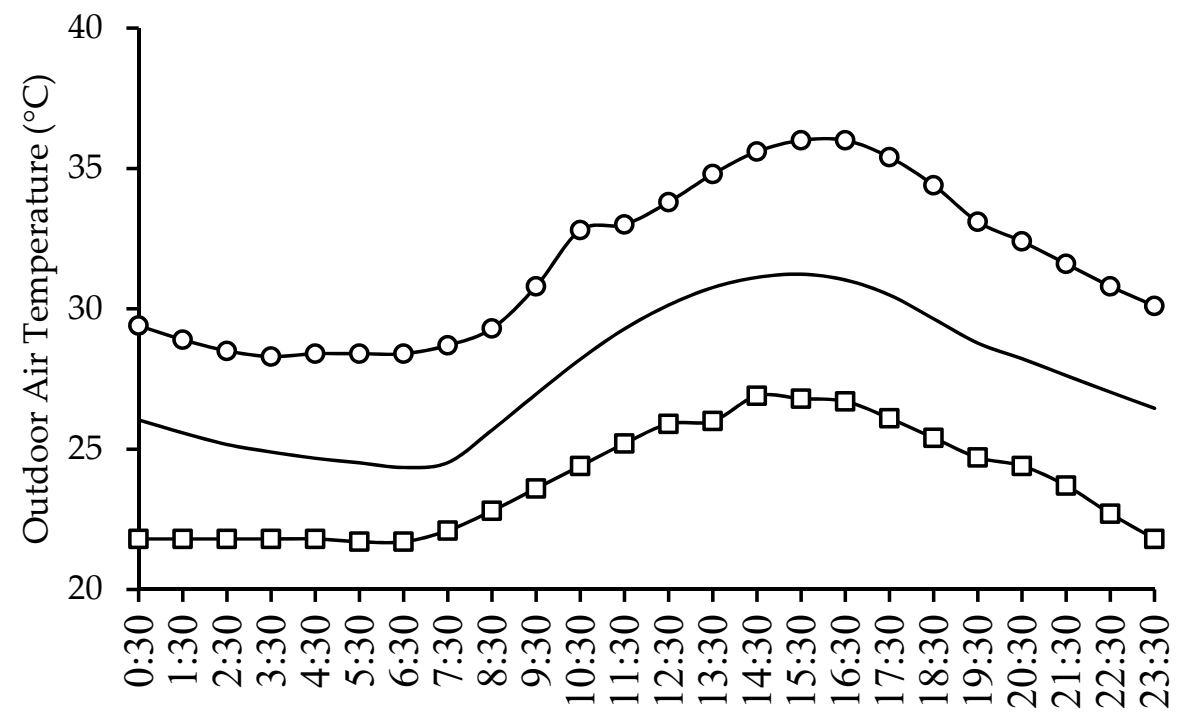

Time

$\longrightarrow$-Minimum -Mean - - Maximum

Figure 10. Annual-averaged profiles of (a) solar irradiance and (b) outdoor air temperature throughout the typical meteorological year of the site location.

Solar reflectance and infrared emittance of the roof surfaces are, as measured in the laboratory, presented in Figure 11. SRI values, as shown in Figure 12, were calculated from the solar reflectance and infrared emittance values, as per Santamouris et al. [42] and ASTM E1980-11 [43]. The change from a conventional to a high-albedo roof surface has led to an increase in the solar reflectance from 0.20 to 0.73 , no change in the infrared emittance at 0.90 , and an increase in the SRI from 19 to 90 . Application of white paint that brought about the high-albedo roof surface can significantly reduce heat transfer through the roof assembly, as, according to Raeissi and Taheri [53], the wavelength of light is reflected by the white pigment at the roof surface and, as a consequence, less solar radiation is absorbed. 


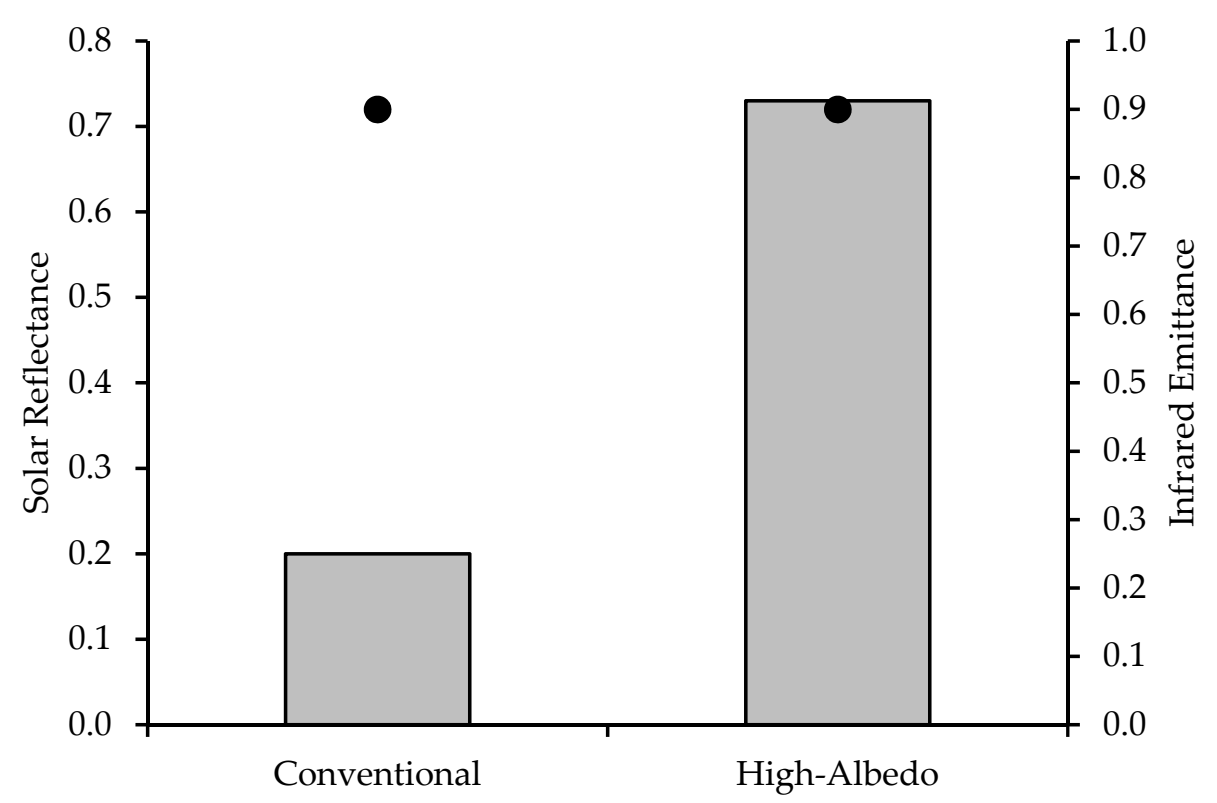

Type of Roof Surface

\section{$\square$ Solar Reflectance $\quad$ Infrared Emittance}

Figure 11. Solar reflectance and infrared emittance of the conventional and high-albedo roof surfaces.

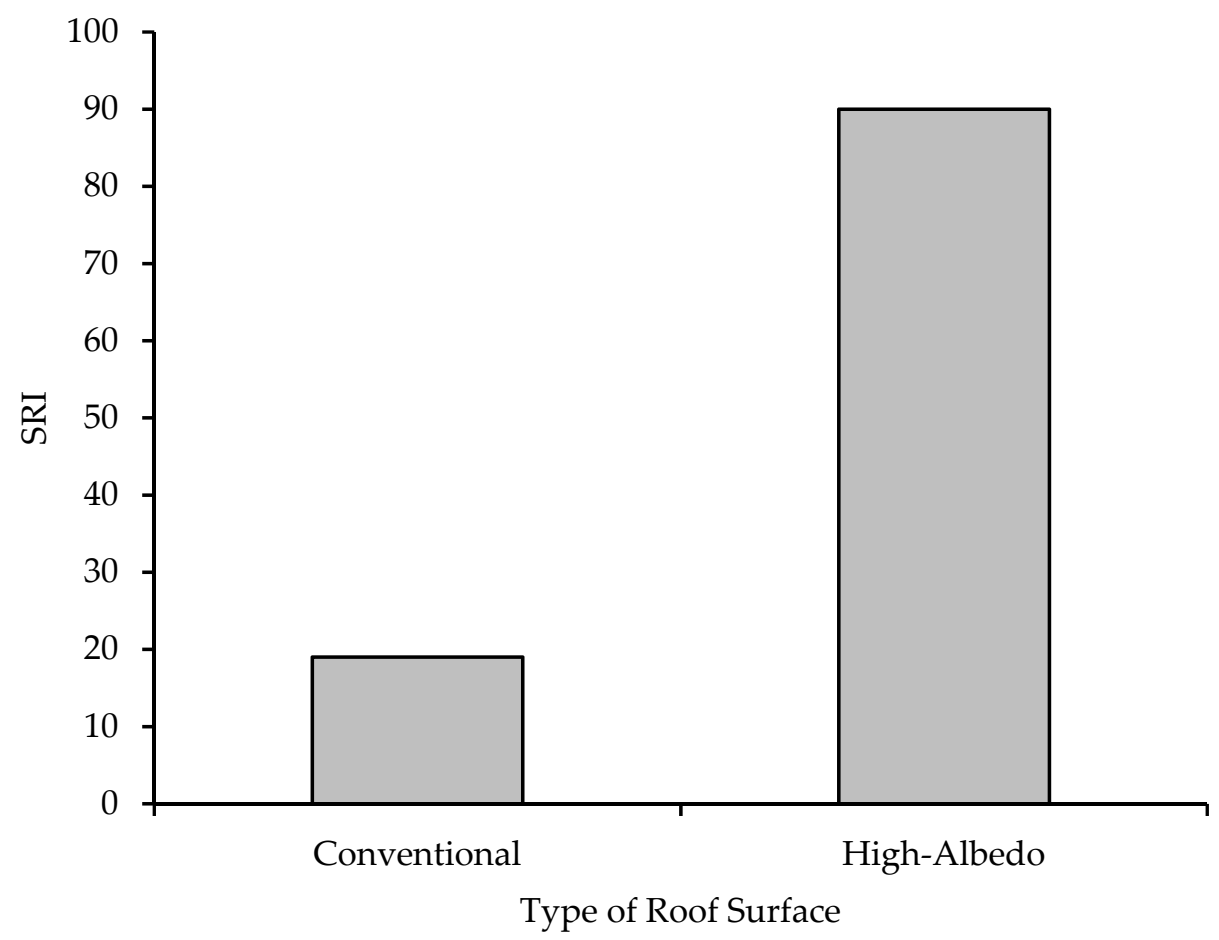

Figure 12. Solar reflectance index (SRI) of the conventional and high-albedo roof surfaces.

Roof surface temperature $\left(T_{R S}\right)$ profiles of the non-insulated conventional and highalbedo roof assemblies are compared in Figure 13. As $T_{R S}$ is heavily influenced by solar irradiance, waveform of the $T_{R S}$ profiles in Figure 13 bears resemblances to that of the solar irradiance profiles in Figure 10. The change from a conventional to a high-albedo roof surface has led to the reduction in $T_{R S}$ throughout the diurnal segment, where $T_{R S}$ culminated at 50.50 and $35.84{ }^{\circ} \mathrm{C}$ for the conventional and high-albedo roof surfaces, respectively. The strong peak reduction of $-14.79^{\circ} \mathrm{C}$ in $T_{R S}$, as illustrated in Figure 14, 
which presents the change in $T_{R S}\left(\Delta T_{R S}\right)$, transpired owing to the relatively higher SRI of the high-albedo roof surface of 90 , in comparison to that of the conventional roof surface of 19. The higher SRI resulted in a higher rate of reflection and accordingly a lower rate of absorption of solar radiation that is incident on the roof surface. As opposed to that of the diurnal segment, the increase in SRI did not influence $T_{R S}$ throughout the nocturnal segment due to the absence of solar radiation throughout the nocturnal period.

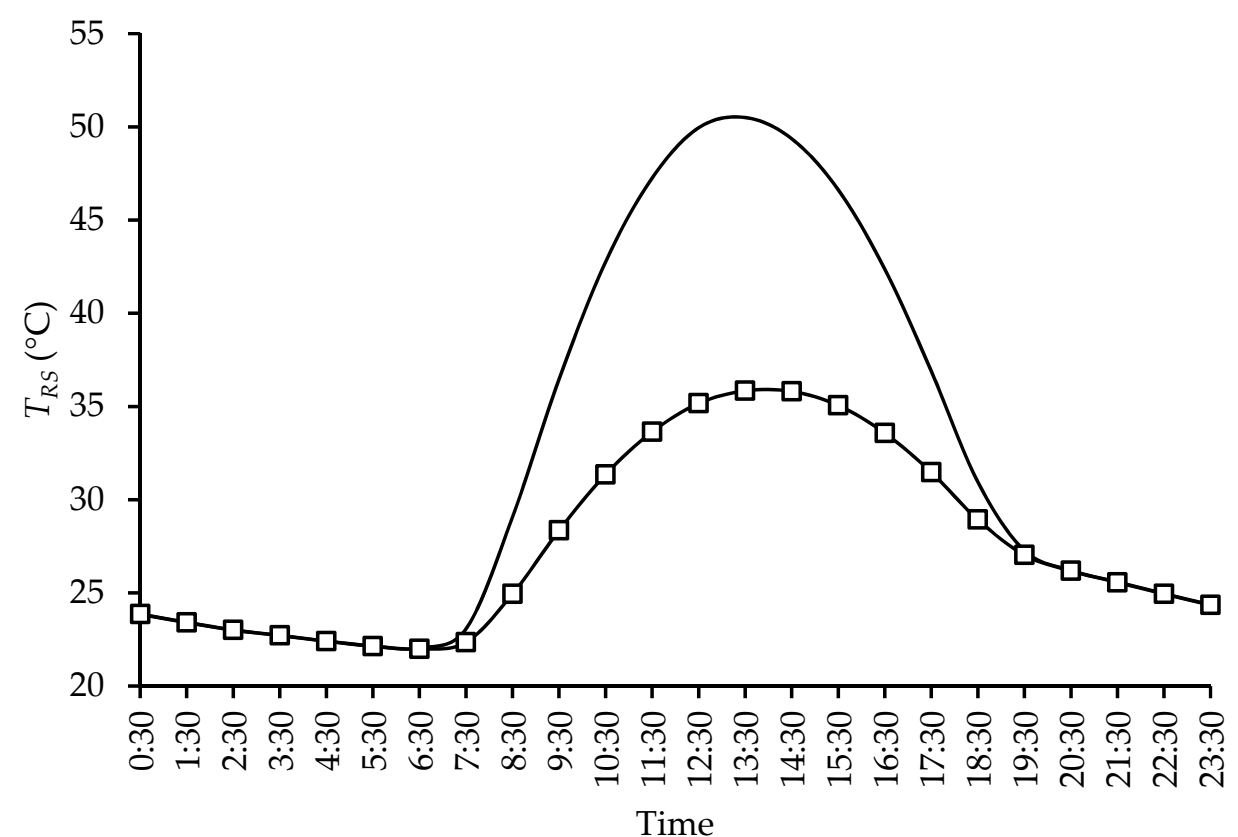

—Conventional (SRI = 19) $\quad \longrightarrow$ - High-Albedo (SRI = 90)

Figure 13. Roof surface temperature $\left(T_{R S}\right)$ profiles of non-insulated roof assemblies.

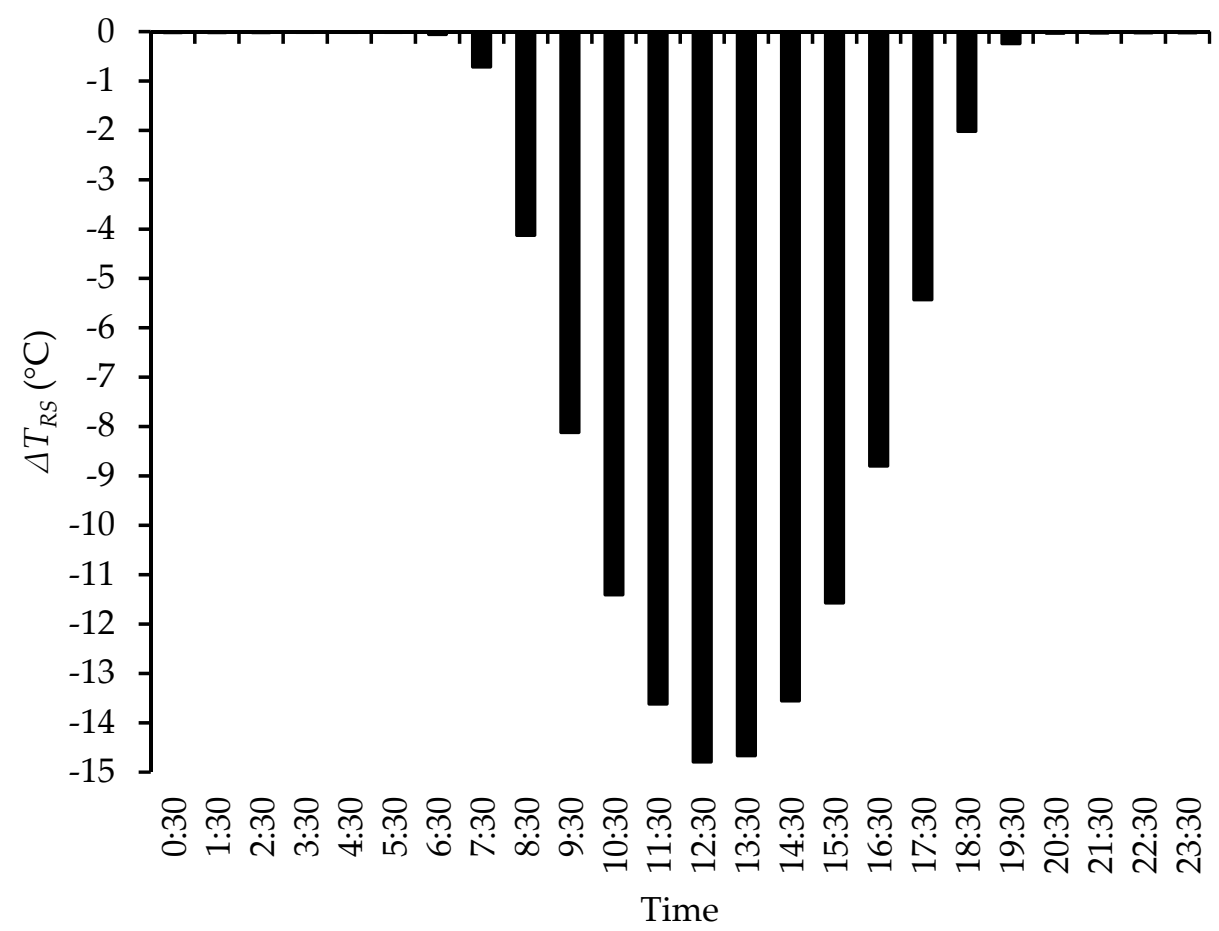

Figure 14. Change in $T_{R S}\left(\Delta T_{R S}\right)$ when SRI was increased from that of the conventional roof assembly $(S R I=19)$ to that of the non-insulated high-albedo roof assembly $(S R I=90)$. 
Plot of $T_{R S}$ versus solar irradiance for the non-insulated conventional and high-albedo roof assemblies are presented in Figure 15. Correlations between $T_{R S}$ and solar irradiance are positive, with coefficient of determination $\left(R^{2}\right)$ values of 0.9662 and 0.8233 , and gradients of 0.0446 and 0.0197 , for the conventional $(S R I=19)$ and high-albedo (SRI $=90)$ roof assemblies, respectively. The lower $\mathrm{R}^{2}$ and gradient for the high-albedo roof assembly signify that the change from the conventional to the high-albedo roof surface has led to the reduction in the influence of solar irradiance on $T_{R S}$ by virtue of the higher rate of reflection and lower rate of absorption of solar radiation on the high-albedo roof surface in comparison to that on the conventional roof surface.

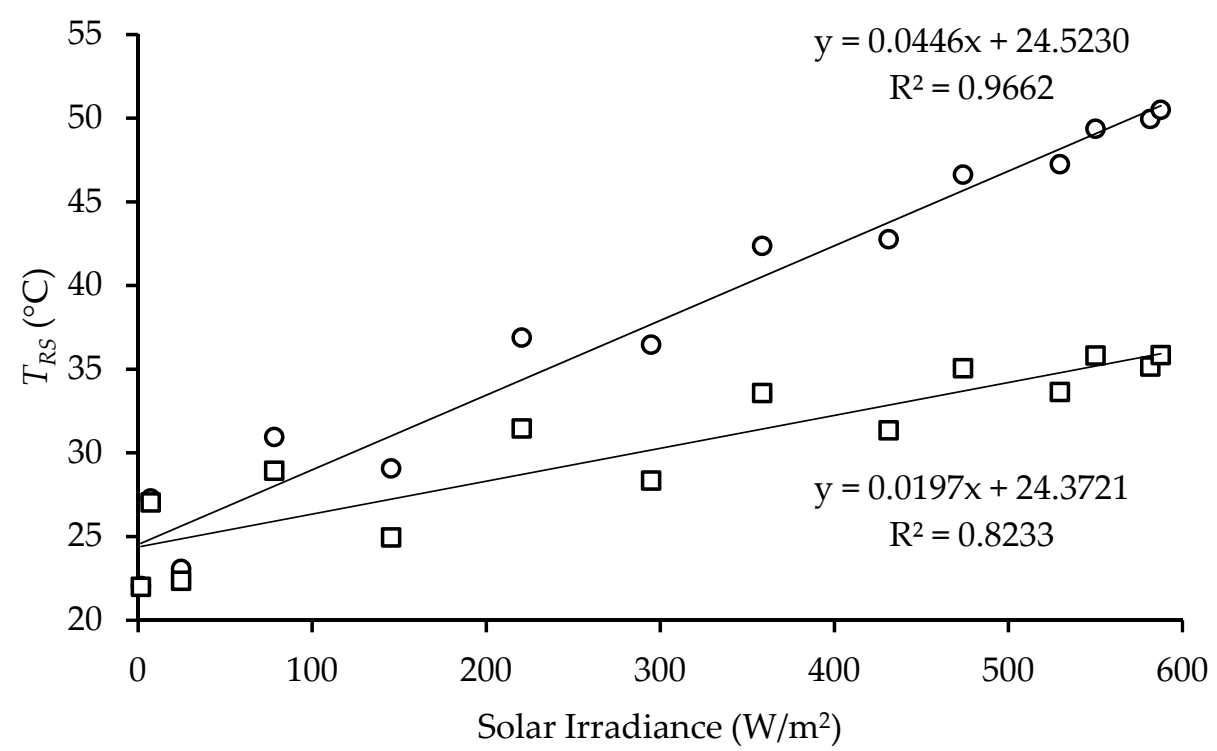

○ Conventional (SRI $=19)$

口 High-Albedo $(S R I=90)$

Linear (Conventional (SRI = 19))

_ Linear (High-Albedo (SRI = 90))

Figure 15. Plot of $T_{R S}$ versus solar irradiance for the non-insulated roof assemblies.

$T_{R S}$ profiles of the non-insulated and insulated high-albedo roof assemblies are compared in Figure 16. The installation of bulk insulation within the high-albedo roof assembly has led to the reduction in $T_{R S}$ throughout the diurnal segment, where the peak $T_{R S}$ further declined from 35.84 to $32.63{ }^{\circ} \mathrm{C}$. The presence of insulation has led to a further peak reduction in $T_{R S}$ of $-4.06^{\circ} \mathrm{C}$ as illustrated in Figure 17, as the insulation material hinders heat conduction through the roof assembly [11]. 


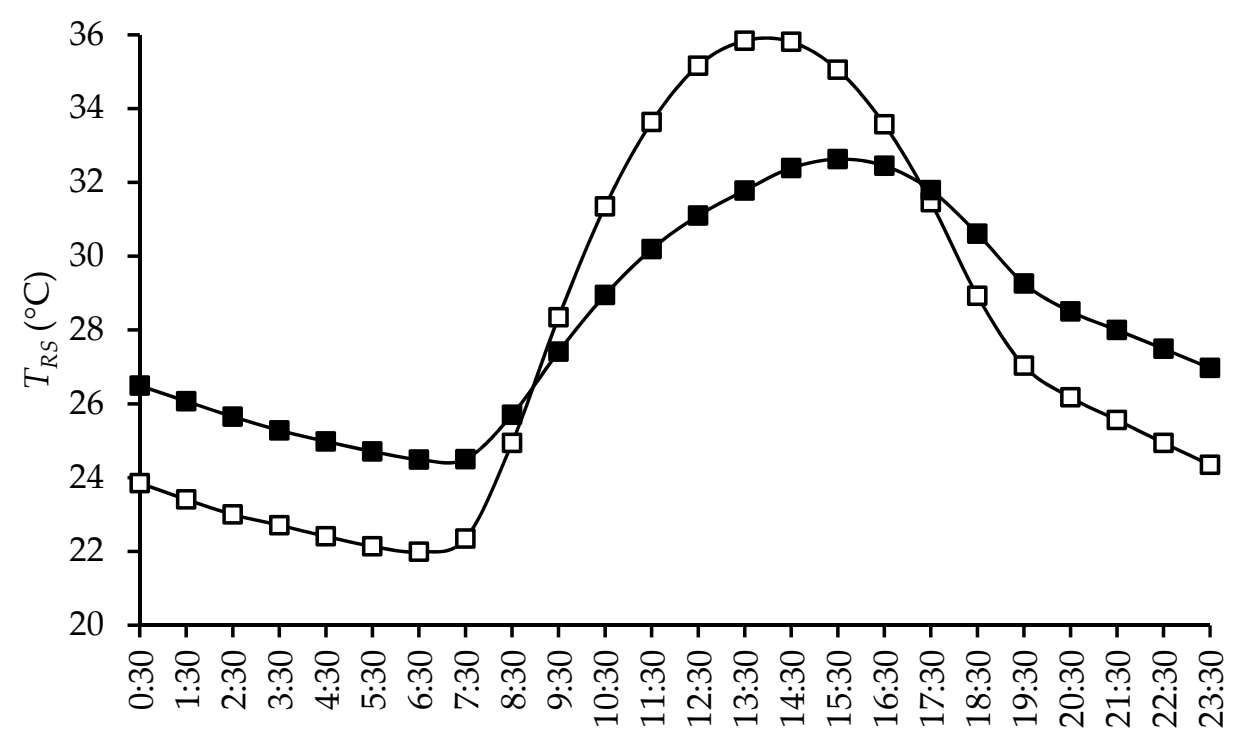

Time

$\rightarrow$-High-Albedo (SRI = 90)

$\rightarrow$ - High-Albedo (SRI = 90) + Bulk Insulation

Figure 16. $T_{R S}$ profiles of high-albedo roof assemblies.

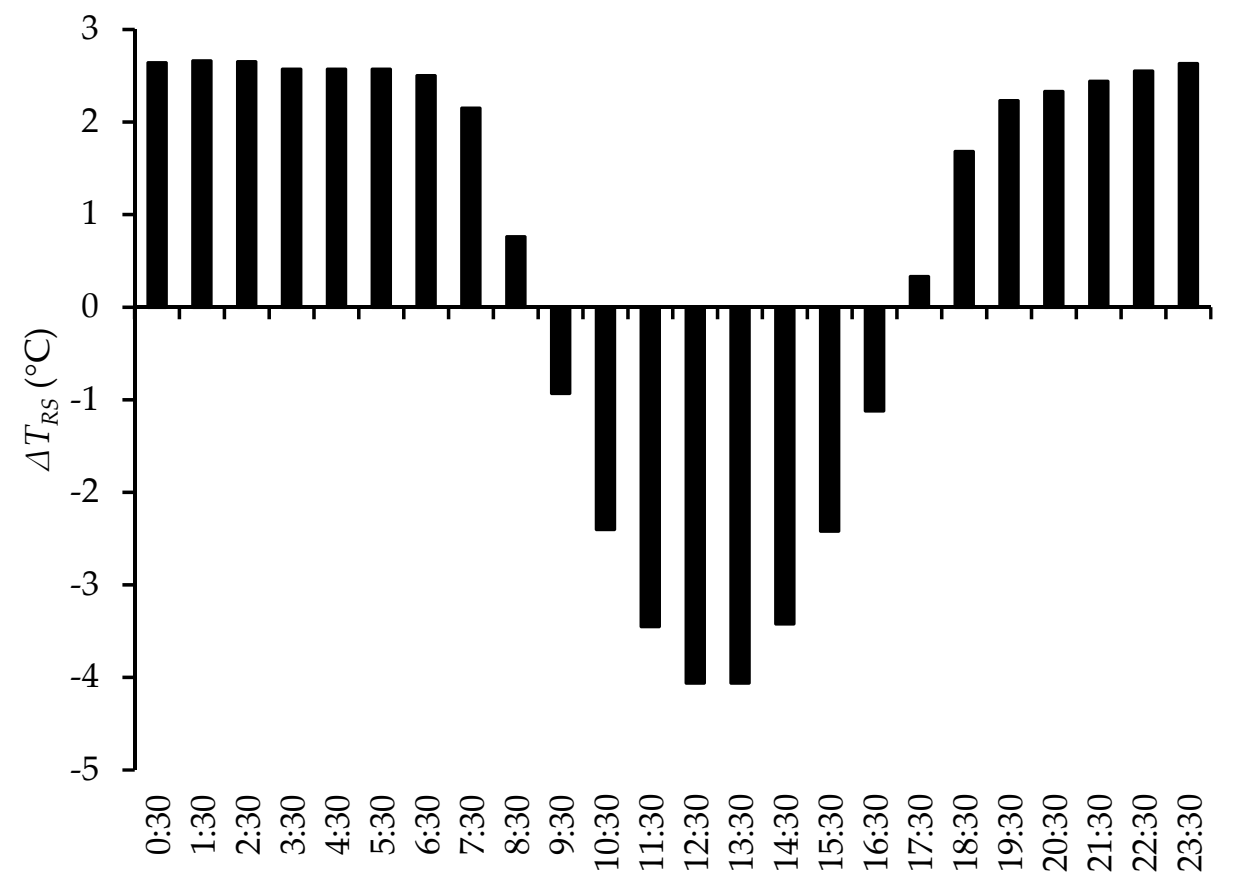

Time

Figure 17. $\Delta T_{R S}$ when bulk insulation was added to the non-insulated high-albedo roof.

Throughout the nocturnal segment, the absence of solar radiation has caused the heat conduction transfer to invert. The transposition occurred due to the reduction in the average effective sky temperature, which resulted in the radiation of heat from the roof surface to the sky during the nocturnal period. Accordingly, heat within the indoor space and roof assembly flows toward the roof tiles and attempts to escape the building to achieve thermal equilibrium as mentioned in Farhan et al. [31] and Tang and Chin [52]. Under the circumstances, the presence of insulation within the roof assembly contributed 
toward hampering the heat transfer out of the building. As a consequence, $T_{R S}$ increased throughout the nocturnal period by up to $2.64^{\circ} \mathrm{C}$, as shown in Figure 17 .

Indoor temperature $\left(T_{i}\right)$ contours were generated at peak diurnal outdoor temperature $\left(T_{o}\right)$ as shown in Figure 18, which was on 17 March at 16:00, and the trough of nocturnal $T_{o}$ as shown in Figure 19, which was on 22 September at 6:00. The contours were generated for all of the configurations of the roof assembly, which were conventional, high-albedo, and high-albedo with bulk insulation. $T_{i}$ contour for the conventional roof assembly discloses that, during peak diurnal $T_{0}$, the high $T_{R S}$, which culminated at $45.00^{\circ} \mathrm{C}$, caused the attic air temperature $\left(T_{A A}\right)$ to elevate to within the range from 39.55 to $43.18^{\circ} \mathrm{C}$. Then, heat transfer into the indoor space resulted in the increase in room air temperature $\left(T_{R A}\right)$ to within the range from 34.09 to $37.73^{\circ} \mathrm{C}$. $T_{i}$ contour for the high-albedo roof assembly exhibits that, resulting from the change from a conventional to a high-albedo roof surface, at peak diurnal $T_{0}$, the range of $T_{R S}$ greatly reduced to within the range from 25.00 to $39.55^{\circ} \mathrm{C}$. The decline in $T_{R S}$ transpired due to the adoption of the high-albedo roof surface, which reduced heat transfer into the attic space. Accordingly, $T_{A A}$ and $T_{R A}$ reduced to within the range from 32.27 to $34.09^{\circ} \mathrm{C}$. $T_{i}$ contour for the high-albedo roof assembly with bulk insulation reveals that the presence of bulk insulation caused $T_{A A}$ and $T_{R A}$ to further reduce to within the range from 30.45 to $32.27^{\circ} \mathrm{C}$ by hampering the heat transfer from the roof surface to the attic space.

\begin{tabular}{|lllll|l|l|l|l|l|l|l|}
\hline & & & & & & & & & & & \\
\hline Temperature 2500 & 2682 & 2864 & 30.45 & 3227 & 3409 & 3591 & 37.73 & 3955 & 4136 & 43.18 & 4500
\end{tabular}

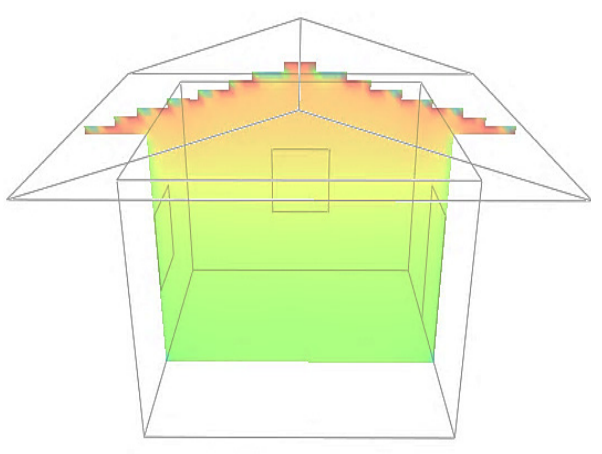

(a)

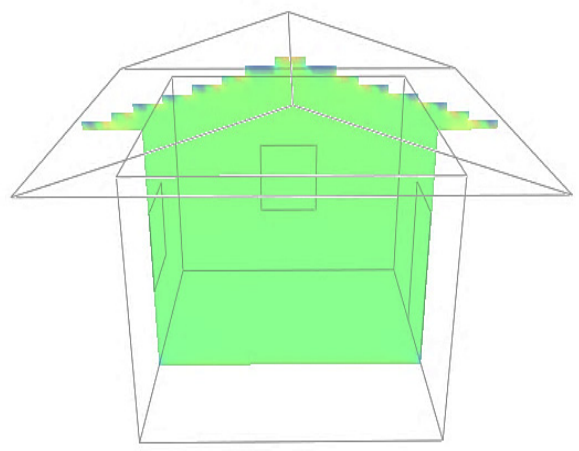

(b)

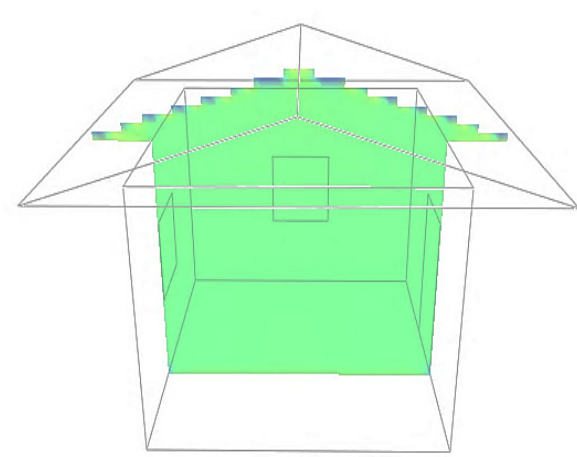

(c)

Figure 18. Indoor temperature $\left(T_{i}\right)$ contours at peak diurnal outdoor temperature $\left(T_{o}\right)$ : $(\mathbf{a})$ conventional, (b) high-albedo and (c) high-albedo with bulk insulation.

At the trough of nocturnal $T_{0}$, increase in the SRI of the roof surface did not influence $T_{R S}, T_{A A}$ and $T_{R A}$ by virtue of the absence of solar radiation, which induced heat radiation from the roof surface to the sky during the nocturnal period and is in agreement with Farhan et al. [31] and Tang and Chin [52]. $T_{R S}$ ranged from 20.00 to $21.36^{\circ} \mathrm{C}$ while $T_{A A}$ and $T_{R A}$ ranged from 21.82 to $22.27^{\circ} \mathrm{C}$. $T_{i}$ contour for the high-albedo roof assembly with bulk insulation shows that, due to the presence of bulk insulation, $T_{R S}, T_{A A}$ and $T_{R A}$ increased owing to the obstruction of heat from escaping the building from the roof surface toward the sky during the nocturnal period. Consequently, heat transfer from the indoor space to the roof surface was hindered.

The change from a conventional to a high-albedo roof surface, followed by the installation of bulk insulation, has resulted in reduction of indoor annual cooling load of the building information model as presented in Figure 20. The indoor annual cooling load reduced from 2.67 MWh for the conventional roof assembly to 2.32 MWh for the highalbedo roof assembly. Installation of bulk insulation within the high-albedo roof assembly has led to further reduction of the indoor annual cooling load from 2.32 to 2.28 MWh. 
Energy savings of $15.13 \%$ have been generated when the change from a conventional to a high-albedo roof surface was performed, while $17.00 \%$ have been generated when the installation of bulk insulation was performed on the high-albedo roof assembly.

\begin{tabular}{|c|c|c|c|c|c|c|c|c|c|c|c|c|}
\hline Temperature 2000 & 20.45 & 2091 & 2136 & 2182 & 2227 & 22.73 & 23.18 & 2364 & 2409 & 2455 & 2500 & ${ }^{\circ} \mathrm{C}$ \\
\hline
\end{tabular}

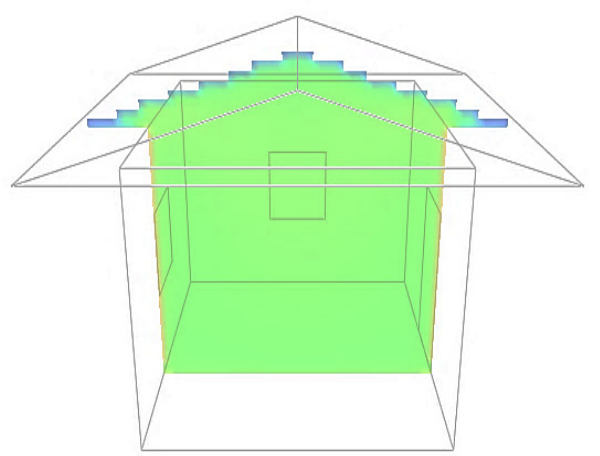

(a)

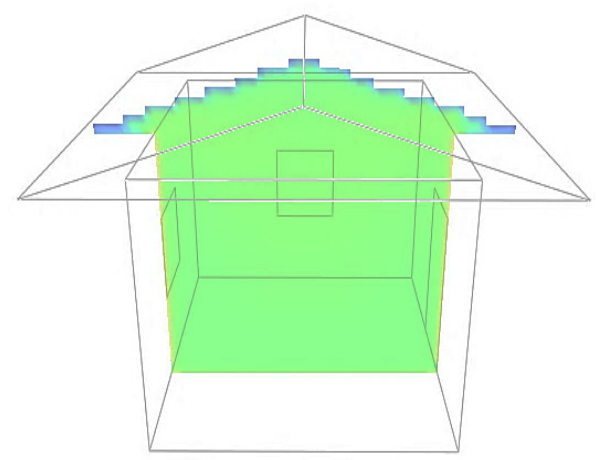

(b)

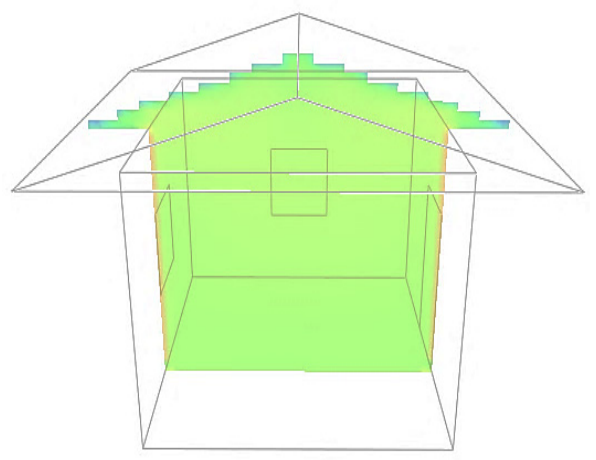

(c)

Figure 19. $T_{i}$ contours at the trough of nocturnal $T_{o}$ : (a) conventional, (b) high-albedo and (c) highalbedo with bulk insulation.

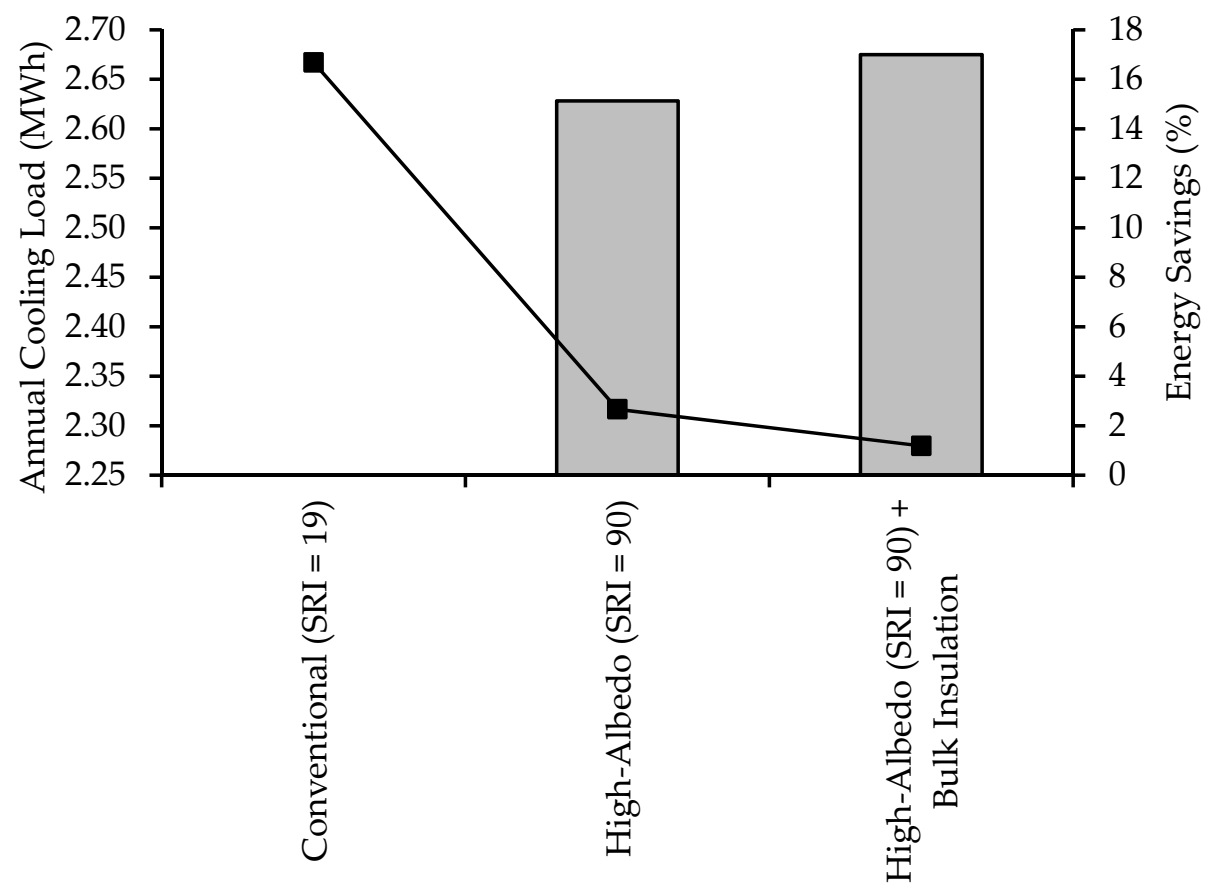

Configuration of Roof Assembly

$\square$ Energy Savings $\rightarrow$-Cooling Load

Figure 20. Annual cooling load and energy savings of the roof assembly at various configurations.

\section{Conclusions}

Thermal-energy performance of an urban pitched residential roof assembly, which adopted varying configurations of high-albedo roof tiles and bulk insulation under the hot, humid climate, was evaluated. Thermal-energy and CFD analyses were performed on a building information model. 
Change from the conventional to the high-albedo roof surface has led to the reduction in the influence of solar irradiance on roof surface temperature due to the higher rate of reflection of solar radiation on the roof surface. However, the change did not influence the roof surface temperature throughout the nocturnal segment due to the absence of solar radiation. Installation of bulk insulation within the high-albedo roof assembly has led to further reduction in roof surface temperature throughout the diurnal segment. However, the reduction coincided with the increase in the roof surface temperature throughout the nocturnal period as heat transfers out of the building, owing to the absence of solar radiation that has caused the direction of heat conduction transfer to invert, which is hampered by the insulation material. Despite the negative impact of installing bulk insulation throughout the nocturnal period, on the whole, energy savings have been achieved, which are 15.13\%, which is from 2.67 to $2.32 \mathrm{MWh}$ when the change from a conventional to a high-albedo roof surface was performed, and $17.00 \%$, which is from 2.32 to $2.28 \mathrm{MWh}$ when the installation of bulk insulation was performed on the high-albedo roof assembly.

For future research, studies that consider the variation in height of the building and surrounding buildings and degree of the placement of high-albedo materials can be considered. Development of a solar-reflective coating that can further increase the solar reflectance of the roof surface and potentially eliminate dependence toward insulation is also recommended. Alternatively, engineering of novel materials that possess extremely low thermal conductivity, which can potentially be applied within the roof assembly with minuscule thicknesses, is proposed.

Author Contributions: Conceptualization, M.D.; methodology, S.A.F.; software, N.S.; validation, H.A.-M.; formal analysis, R.I.; investigation, M.D.; resources, N.S.; data curation, H.A.-M.; writingoriginal draft preparation, S.A.F.; writing-review and editing, M.D. and S.A.F.; visualization, R.I.; supervision, N.S.; project administration, H.A.-M.; funding acquisition, R.I. All authors have read and agreed to the published version of the manuscript.

Funding: The Article Processing Charge was self-funded by the authors. The research also received financial support from Yayasan Universiti Teknologi PETRONAS (UTP), Malaysia, via grant number 015LC0-155, which was administered by Research Management Center of UTP.

Institutional Review Board Statement: Not applicable.

Informed Consent Statement: Not applicable.

Data Availability Statement: The data presented in this study are available on request from the corresponding author, S.A.F.

Acknowledgments: The authors are thankful to the Institute of Science of Universiti Teknologi MARA Shah Alam, Malaysia, as well as Yarmouk University and Jadara University, Jordan, for the support and collaboration.

Conflicts of Interest: The authors declare no conflict of interest.

\title{
Nomenclature
}

\author{
Abbreviations \\ BIM Building Information Modeling \\ CFD Computational Fluid Dynamics \\ IESVE Integrated Environmental Solutions < Virtual Environment> \\ $k$-value Thermal conductivity \\ $R$-value Thermal resistance \\ SRI Solar Reflectance Index \\ TMY Typical Meteorological Year
}




Notations
$A$
$A_{1}$
$\frac{d T}{d x}$
$F M$
$h_{c}$
$h_{r}$
$k$
$P D_{S D-F M}$
$Q_{\text {conduction }}$
$Q_{\text {convection }}$
$Q_{\text {radiation }}$
$S D$
$T_{A A}$
$T_{\text {black }}$
$T_{f}$
$T_{i}$
$T_{o}$
$T_{R S}$
$T_{S}$
$T_{\text {surface }}$
$T_{\text {white }}$
$T_{1}$
$T_{2}$
$\Delta T_{R S}$
$\varepsilon_{1}$
$\sigma$

Cross-sectional area perpendicular to heat flow (for calculation of $Q_{\text {conduction }}$ ), or surface area (for calculation of $Q_{\text {convection }}$ )

Area of the first surface

Temperature gradient

Field measurement data

Surface heat transfer coefficient

Coefficient of heat transfer

Thermal conductivity

Percentage difference between the simulation and field measurement data

Heat transfer by conduction

Heat transfer by convection

Heat transfer by radiation

Simulation data

Attic air temperature

Steady-state temperature of the standard black

Fluid temperature

Indoor temperature

Outdoor temperature

Roof-top surface temperature

Surface temperature

Steady-state temperature of the material surface

Steady-state temperature of the standard white

Absolute temperature of the first surface

Absolute temperature of the second surface

Change in roof-top surface temperature

Emissivity of the first surface

Stefan-Boltzmann constant

\section{References}

1. Alam, S.S.; Omar, N.A.; Ahmad, M.S.; Siddiquei, H.R.; Nor, S.M. Renewable energy in Malaysia: Strategies and development. Environ. Manag. Sustain. Dev. 2013, 2, 51-66. [CrossRef]

2. Al-Obaidi, K.M.; Ismail, M.; Abdul Rahman, A.M. Passive cooling techniques through reflective and radiative roofs in tropical houses in Southeast Asia: A literature review. Front. Archit. Res. 2014, 3, 283-297. [CrossRef]

3. Miranville, F.; Boyer, H.; Mara, T.; Garde, F. On the thermal behaviour of roof-mounted radiant barriers under tropical and humid climatic conditions: Modelling and empirical validation. Energy Build. 2003, 35, 997-1008. [CrossRef]

4. Al-Obaidi, K.M.; Ismail, M.; Abdul Rahman, A.M. Investigation of passive design techniques for pitched roof systems in the tropical region. Mod. Appl. Sci. 2014, 8, 182-191. [CrossRef]

5. Tang, K.H.D. Climate change in Malaysia: Trends, contributors, impacts, mitigation and adaptations. Sci. Total Environ. 2019, 650, 1858-1871. [CrossRef]

6. $\quad$ Beck, H.E.; Zimmermann, N.E.; McVicar, T.R.; Vergopolan, N.; Berg, A.; Wood, E.F. Present and future Köppen-Geiger climate classification maps at 1-km resolution. Sci. Data 2018, 5, 180214. [CrossRef]

7. MetMalaysia: Maklumat Iklim. Available online: https://www.met.gov.my/iklim/laporanringkasan/maklumatiklim (accessed on 11 January 2022).

8. MetMalaysia: Iklim Malaysia. Available online: https://www.met.gov.my/pendidikan/iklim/iklimmalaysia (accessed on 11 January 2022).

9. Mekhilef, S.; Safari, A.; Mustaffa, W.E.S.; Saidur, R.; Omar, R.; Younis, M.A.A. Solar energy in Malaysia: Current state and prospects. Renew. Sustain. Energy Rev. 2012, 16, 386-396. [CrossRef]

10. Vijaykumar, K.C.K.; Srinivasan, P.S.S.; Dhandapani, S. A performance of hollow clay tile (HCT) laid reinforced cement concrete (RCC) roof for tropical summer climates. Energy Build. 2007, 39, 886-892. [CrossRef]

11. Tuck, N.W.; Zaki, S.A.; Hagishima, A.; Rijal, H.B.; Yakub, F. Affordable retrofitting methods to achieve thermal comfort for a terrace house in Malaysia with a hot-humid climate. Energy Build. 2020, 223, 110072. [CrossRef]

12. Papadopoulos, A.M.; Giama, E. Environmental performance evaluation of thermal insulation materials and its impact on the building. Build. Environ. 2007, 42, 2178-2187. [CrossRef]

13. Husna, N.; Farhan, S.A.; Abdul Wahab, M.M.; Shafiq, N.; Sharif, M.T.; Abd Razak, S.N.; Ismail, F.I. Effect of granular silica aerogel as filler on tensile and flexural strengths and moduli of stone-wool-fibre-reinforced composite as rigid board roof insulation material. IOP Conf. Ser. Earth Environ. Sci. 2021, 945, 012061. [CrossRef] 
14. Ismail, F.I.; Farhan, S.A.; Shafiq, N.; Husna, N.; Sharif, M.T.; Affan, S.U.; Veerasenan, A.K. Nano-porous silica-aerogel-incorporated composite materials for thermal-energy-efficient pitched roof in the tropical region. Appl. Sci. 2021, 11, 6081. [CrossRef]

15. Nuruddin, M.F.; Husna, N.; Azizli, K.A.M.; Farhan, S.A.; Wan Zainal Abidin, W.A.A. Prospect of adopting kapok fibre as roof insulation. Appl. Mech. Mater. 2014, 567, 482-487. [CrossRef]

16. Farhan, S.A.; Khamidi, M.F.; Husna, N. Thickness optimization of kapok fibre insulation below roof pitch of residential buildings in hot-humid climate with mathematical formulation. Appl. Mech. Mater. 2014, 699, 864-870. [CrossRef]

17. Omar, M.F.; Abdullah, M.A.H.; Rashid, N.A.; Abdul Rani, A.L.; Illias, N.A. The application of coconut fiber as insulation ceiling board in building construction. IOP Conf. Ser. Mater. Sci. Eng. 2020, 864, 012196. [CrossRef]

18. Al Yacouby, A.M.; Khamidi, M.F.; Teo, Y.W.; Nuruddin, M.F.; Farhan, S.A.; Sulaiman, S.A.; Razali, A.E. Housing developers and home owners awareness on implementation of building insulation in Malaysia. WIT Trans. Ecol. Environ. 2011, 148, 219-230. [CrossRef]

19. MS 2680:2017; Energy Efficiency and Use of Renewable Energy for Residential Buildings—Code of Practice. Malaysian Standard: Cyberjaya, Malaysia, 2017.

20. Green Building Index Assessment Criteria for Residential New Construction Version 3.0. Available online: https://www. greenbuildingindex.org/Files/Resources/GBI\%20Tools/GBI\%20RNC\%20Residential\%20Tool\%20V3.0.pdf (accessed on 11 January 2022).

21. Sel. P.U. 142/2012; Selangor Uniform Building (Amendment) (No. 2) By-Laws 2012. State of Selangor: Putrajaya, Malaysia, 2012.

22. Farhan, S.A.; Khamidi, M.F.; Al Yacouby, A.M.; Idrus, A.; Nuruddin, M.F. Critical Review of Published Research on Building Insulation: Focus on Building Components and Climate. In Proceedings of the 2012 IEEE Business, Engineering \& Industrial Applications Colloquium (BEIAC 2012), Kuala Lumpur, Malaysia, 7-8 April 2012. [CrossRef]

23. Halim, N.H.A.; Zain-Ahmed, A.; Zakaria, N.Z. Thermal and Energy Analysis of Ceiling and Pitch Insulation for Buildings in Malaysia. In Proceedings of the 3rd International Symposium \& Exhibition in Sustainable Energy \& Environment (ISESEE 2011), Malacca, Malaysia, 1-3 June 2011. [CrossRef]

24. Irwan, S.S.; Zain-Ahmed, A.; Zakaria, N.Z.; Ibrahim, N. Thermal and energy performance of conditioned building due to insulated sloped roof. AIP Conf. Proc. 2010, 1250, 476. [CrossRef]

25. Irwan, S.S.; Zain-Ahmed, A.; Ibrahim, N.; Zakaria, N.Z. Roof Angle for Optimum Thermal and Energy Performance of Insulated Roof. In Proceedings of the 3rd International Conference on Energy and Environment (ICEE 2009), Malacca, Malaysia, 7-8 December 2009. [CrossRef]

26. Morris, F.; Zain-Ahmed, A.; Zakaria, N.Z. Thermal Performance of Naturally Ventilated Test Building with Pitch and Ceiling Insulation. In Proceedings of the 3rd International Symposium \& Exhibition in Sustainable Energy \& Environment (ISESEE 2011), Malacca, Malaysia, 1-3 June 2011. [CrossRef]

27. Nuruddin, M.F.; Puad, N.H.A.; Zaidi, N.H.A. Effectiveness of aerogel roofing system on temperature reduction in Malaysian residential buildings. J. Eng. Appl. Sci. 2017, 12, 4057-4062. [CrossRef]

28. Puad, N.H.A.; Nuruddin, M.F.; Lian, J.J.; Othman, I. Roof Insulation Material from Low Density Polyethylene (LDPE), Kapok Fibre and Silica Aerogel. In Engineering Challenges for Sustainable Future, Proceedings of the 3rd International Conference on Civil, Offshore and Environmental Engineering (ICCOEE 2016), Kuala Lumpur, Malaysia, 15-17 August 2016; CRC Press: Boca Raton, FL, USA, 2016. [CrossRef]

29. Zakaria, N.Z.; Zain-Ahmed, A.; Ariffin, N.N.; Abdul Halim, N.H.; Morris, F. Thermal Energy Evaluation of Building with Ceiling Insulation in Warm-Humid Tropical Climate. In Proceedings of the 2011 IEEE Colloquium on Humanities, Science and Engineering (CHUSER 2011), Penang, Malaysia, 5-6 December 2011. [CrossRef]

30. Al Yacouby, A.M.; Khamidi, M.F.; Nuruddin, M.F.; Farhan, S.A.; Razali, A.E. Study on Roof Tile's Colors in Malaysia for Development of New Anti-Warming Roof Tiles with Higher Solar Reflectance Index (SRI). In Energy and Sustainability: Exploring the Innovative Minds, Proceedings of the National Postgraduate Conference (NPC 2011), Perak, Malaysia, 19-20 September 2011; IEEE: Piscataway, NJ, USA, 2011.

31. Farhan, S.A.; Ismail, F.I.; Kiwan, O.; Shafiq, N.; Zain-Ahmed, A.; Husna, N.; Hamid, A.I.A. Effect of roof tile colour on heat conduction transfer, roof-top surface temperature and cooling load in modern residential buildings under the tropical climate of Malaysia. Sustainability 2021, 13, 4665. [CrossRef]

32. Synnefa, A.; Santamouris, M.; Akbari, H. Estimating the effect of using cool coatings on energy loads and thermal comfort in residential buildings in various climatic conditions. Energy Build. 2007, 39, 1167-1174. [CrossRef]

33. Pisello, A.L. High-albedo roof coatings for reducing building cooling needs. In Eco-Efficient Materials for Mitigating Building Cooling Needs-Design, Properties and Applications; Woodhead Publishing: Cambridge, UK, 2015; pp. 243-268. [CrossRef]

34. Syuhada, A.; Maulana, M.I. Heat transfer capability of solar radiation in colored roof and influence on room thermal comfort. AIP Conf. Proc. 2018, 1931, 030054. [CrossRef]

35. Zingre, K.T.; Wan, M.P.; Wong, S.K.; Toh, W.B.T.; Lee, I.Y.L. Modelling of cool roof performance for double-skin roofs in tropical climate. Energy 2015, 82, 813-826. [CrossRef]

36. Thongkanluang, T.; Chirakanphaisarn, N.; Limsuwan, P. Preparation of NIR reflective brown pigment. Procedia Eng. 2012, 32, 895-901. [CrossRef]

37. G.N. 5178/85; UBBL 1984. Uniform Building By-Laws 1984. International Law Book Services: Petaling Jaya, Malaysia, 2013. 
38. Sekerka, R.F. Thermodynamics and Statistical Mechanics for Scientists and Engineers; Elsevier Inc.: Amsterdam, The Netherlands, 2015. [CrossRef]

39. Jayamaha, L. Energy Efficient Building Systems: Green Strategies for Operation and Maintenance; McGraw-Hill: New York, NY, USA, 2006.

40. Ghiaasiaan, S.M. Convective Heat and Mass Transfer; Cambridge University Press: New York, NY, USA, 2011.

41. Howell, J.R.; Siegel, R.; Mengüç, M.P. Thermal Radiation Heat Transfer, 5th ed.; CRC Press: Boca Raton, FL, USA, 2011.

42. Santamouris, M.; Synnefa, A.; Karlessi, T. Using advanced cool materials in the urban built environment to mitigate heat islands and improve thermal comfort conditions. Sol. Energy 2011, 85, 3085-3102. [CrossRef]

43. ASTM E1980-11; Standard Practice for Calculating Solar Reflectance Index of Horizontal and Low-Sloped Opaque Surfaces. ASTM: West Conshohocken, PA, USA, 2019.

44. Amir, A.; Mohamed, M.F.; Sulaiman, M.K.A.; Yusoff, W.F.M. Assessment of indoor thermal condition of a low-cost single story detached house: A case study in Malaysia. Alam Cipta 2019, 12, 80-88.

45. Gardezi, S.S.S.; Shafiq, N.; Wan Abdullah Zawawi, N.A.; Khamidi, M.F.; Farhan, S.A. Minimization of embodied carbon footprint from housing sector of Malaysia. Chem. Eng. Trans. 2015, 45, 1927-1932. [CrossRef]

46. Jamaludin, N.; Mohammed, N.I.; Farhan, S.A. Indoor Thermal Environment in Residential Buildings at Different Micro-Climates in Malaysia. In Recent Advances in Environmental and Biological Engineering, Proceedings of the 3rd International Conference on Sustainable Cities, Urban Sustainability and Transportation (SCUST '14), Istanbul, Turkey, 15-17 December 2014; WSEAS Press: Athens, Greece, 2014.

47. Vangimalla, P.R.; Olbina, S.J.; Issa, R.R.; Hinze, J. Validation of Autodesk Ecotect ${ }^{\mathrm{TM}}$ Accuracy for Thermal and Daylighting Simulations. In Proceedings of the 2011 Winter Simulation Conference, Phoenix, AZ, USA, 11-14 December 2011.

48. Leng, P.C.; Ahmad, M.H.; Ossen, D.R.; Hamid, M. Investigation of Integrated Environmental Solutions-Virtual Environment Software Accuracy for Air Temperature and Relative Humidity of the Test Room Simulations. In Proceedings of the Universiti Malaysia Terengganu 11th International Annual Symposium on Sustainability Science and Management, Terengganu, Malaysia, 9-11 July 2012.

49. Maamari, F.; Andersen, M.; de Boer, J.; Carroll, W.L.; Dumortier, D.; Greenup, P. Experimental validation of simulation methods for bi-directional transmission properties at the daylighting performance level. Energy Build. 2006, 38, 878-889. [CrossRef]

50. Meteonorm: Global Climate Database. Available online: https:/ / meteonorm.com (accessed on 11 January 2022).

51. MS 1525:2019; Energy Efficiency and Use of Renewable Energy for Non-Residential Buildings—Code of Practice (Third Revision). Malaysian Standard: Cyberjaya, Malaysia, 2019.

52. Tang, C.K.; Chin, N. Building Energy Efficiency Technical Guideline for Passive Design; Building Sector Energy Efficiency Project (BSEEP): Kuala Lumpur, Malaysia, 2013.

53. Raeissi, S.; Taheri, M. Cooling load reduction of buildings using passive roof options. Renew. Energy 1996, 7, 301-313. [CrossRef] 